\title{
Establishment and characterization of pleomorphic adenoma cell systems: an in-vitro demonstration of carcinomas arising secondarily from adenomas in the salivary gland
}

\author{
Satoshi Maruyama1,2, Jun Cheng ${ }^{1}$, Susumu Shingaki ${ }^{3}$, Takashi Tamura ${ }^{4}$, \\ Shuichi Asakawa ${ }^{5}$, Shinsei Minoshima ${ }^{6}$, Yoshiko Shimizu ${ }^{4}$, \\ Nobuyoshi Shimizu ${ }^{7}$ and Takashi Saku*1,2
}

\begin{abstract}
Address: ${ }^{1}$ Divisions of Oral Pathology, Department of Tissue Regeneration and Reconstruction, Niigata University, Graduate School of Medical and Dental Sciences, 2-5274 Gakkoucho-dori, Chuo-ku, Niigata 951-8514, Japan, ${ }^{2}$ Oral Pathology Section, Department of Surgical Pathology, Niigata University Hospital 1-754, Asahimachi-dori, Chuo-ku, Niigata 951-8520, Japan, ${ }^{3}$ Divisions of Reconstructive Surgery for Oral and Maxillofacial Region, Department of Tissue Regeneration and Reconstruction, Niigata University, Graduate School of Medical and Dental Sciences, 2-5274 Gakkoucho-dori, Chuo-ku, Niigata 951-8514, Japan, ${ }^{4}$ Department of Medical Genetics, School of Health Sciences, Kyorin University, 476 Miyashita-cho, Hachioji-shi, Tokyo 192-8508, Japan, ${ }^{5}$ Department of Molecular Biology, Keio University School of Medicine, 35 Shinanomachi, Shinjuku-ku, Tokyo 160-8582, Japan, ${ }^{6}$ Medical Photobiology Department, Photon Medical Research Center, Hamamatsu University School of Medicine, 1-20-1 Handayama, Hamamatsu 431-3192, Japan and 7Advanced Research Center for Genome Super Power, Keio University, 2 Okubo, Tsukuba, Ibaraki 300-2611, Japan

Email: Satoshi Maruyama - maru@dent.niigata-u.ac.jp; Jun Cheng - jun@dent.niigata-u.ac.jp; Susumu Shingaki - shingaki@dent.niigata-u.ac.jp; Takashi Tamura - ttamura@kyorin-u.ac.jp; Shuichi Asakawa - asa@dmb.med.keio.ac.jp; Shinsei Minoshima - mino@hama-med.ac.jp;

Yoshiko Shimizu - yshimizu@kyorin-u.asc.jp; Nobuyoshi Shimizu - smzgsp@dmb.med.keio.ac.jp; Takashi Saku* - tsaku@dent.niigata-u.ac.jp

* Corresponding author
\end{abstract}

Published: 21 July 2009

BMC Cancer 2009, 9:247 doi:10.1 186/147/-2407-9-247
Received: 14 October 2008

Accepted: 21 July 2009

This article is available from: http://www.biomedcentral.com/I47I-2407/9/247

(C) 2009 Maruyama et al; licensee BioMed Central Ltd.

This is an Open Access article distributed under the terms of the Creative Commons Attribution License (http://creativecommons.org/licenses/by/2.0), which permits unrestricted use, distribution, and reproduction in any medium, provided the original work is properly cited.

\begin{abstract}
Background: Among the salivary gland carcinomas, carcinoma in pleomorphic adenoma has been regarded as a representative carcinoma type which arises secondarily in the background of a preexistent benign pleomorphic adenoma. It is still poorly understood how and which benign pleomorphic adenoma cells transform into its malignant form, carcinoma ex pleomorphic adenoma.

Methods: We have established five cell systems from a benign pleomorphic adenoma of the parotid gland of a 61 -year-old woman. They were characterized by immunofluorescence, classical cytogenetics, $p 53$ gene mutational analysis, fluorescence in-situ hybridization, and histopathological and immunohistochemical examinations of their xenografts, to demonstrate their potency of secondary transformation.

Results: We established and characterized five cell systems (designated as SM-API to SM-AP5) from a benign pleomorphic adenoma of the parotid gland. SM-API to SM-AP3 showed polygonal cell shapes while SM-AP4 and SM-AP5 were spindle-shaped. SM-API-3 cells were immunopositive for keratin only, indicating their duct-epithelial or squamous cell differentiation, while SM-AP4/5 cells were positive for both keratin and S-100 protein, indicating their myoepithelial cell differentiation. Chromosome analyses showed numeral abnormalities such as $5 \mathrm{n}$ ploidies and various kinds of structural abnormalities, such as deletions, translocations, derivatives and isodicentric chromosomes. Among them, $\operatorname{der}(9) \mathrm{t}(9 ; \mid 3)(\mathrm{p}|3.3 ; \mathrm{q}| 2.3)$ was shared by all five of the cell systems. In addition, they all had a common deletion of the last base G of codon 249 (AGG to
\end{abstract}


AG_) of the p53 gene, which resulted in generation of its nonsense gene product. Transplanted cells in nude mice formed subcutaneous tumors, which had histological features of squamous cell carcinoma with apparent keratinizing tendencies. In addition, they had ductal arrangements or plasmacytoid appearances of tumor cells and myxoid or hyaline stromata, indicating some characteristics of pleomorphic adenoma.

Conclusion: This study demonstrates in vitro that certain cell types from pleomorphic adenoma are able to clone and survive over a long term and develop subcutaneous tumors in nude mice. The histological features of squamous cell carcinoma from the transplanted cell systems in nude mice might suggest a secondary onset of malignancy from a pre-existing benign adenoma.

\section{Background}

Among the salivary gland carcinomas, carcinoma ex pleomorphic adenoma has been regarded as only one carcinoma type, which is considered to arise in the background of a pre-existent benign adenoma. The frequencies of the secondary onset of carcinoma have been recorded to be $6.2 \%$ to $8.8 \%$ among pleomorphic adenomas, although cellular mechanisms for how carcinoma cells develop in pleomorphic adenomas are poorly understood [1,2]. In our previous study, we proposed a concept of focal carcinomas in pleomorphic adenoma which is an advanced stage of accumulated atypical cells with P53 over-expressions as an initial stage or a latent form of apparent carcinomas secondarily arising in pleomorphic adenoma [3]. Although pathologists in their daily services of surgical pathology had recognized such singular atypical cells in pleomorphic adenomas, these atypical cells were not always regarded as evidence or the source for malignant transformation [4-6].

Pleomorphic adenomas have been often subjected to cytogenetic and molecular analyses. Among those studies, the PLAG1 (pleomorphic adenoma-related gene), which is located in 8q12, has been investigated most extensively. PLAG1 is consistently rearranged in pleomorphic adenoma by translocations $\mathrm{t}(3 ; 8)(\mathrm{p} 21 ; \mathrm{q} 12) \quad[7,8]$ and $\mathrm{t}(5 ; 8)(\mathrm{p} 13 ; \mathrm{q} 12)$ [9]. These translocations have been regarded as one of the major responsible genetic events for the tumorigenesis of pleomorphic adenoma. As another important cancer-related gene, the p53 gene has been most extensively investigated in surgical samples of both benign pleomorphic adenoma, focal carcinoma in pleomorphic adenoma [3] and carcinoma ex pleomorphic adenoma [10-18], and mutations in the p53 gene have been considered to be responsible for the malignant transformation of pleomorphic adenoma [10-12].

There have been three trials in the literature to establish cell lines/systems from pleomorphic adenomas [19-21] and two from carcinoma ex pleomorphic adenomas $[13,22]$, in addition to those from mere primary cultures [7-9,23-27]. Kondo et al. [19] established an epithelial cell line named Nagoya-78 from a benign pleomorphic ade- noma of the lip and showed that the cells contained 6265 chromosomes with plenty of abnormalities. They also transplanted the cells in hamsters, whose histological phenotypes were malignant myoepitheliomas, to generate tumors within a few weeks. Jaeger et al. [20] also established a cell line named AP2 from a benign pleomorphic adenoma of the parotid gland, which showed myoepithelial-like characteristics in a three dimensional culture. Another cell line from a palatal pleomorphic adenoma was HPA by Shirasuna et al. [21]. This cell line was revealed ultrastructurally to show a myoepithelial differentiation. These reports described malignant or transformed natures of the cells, while no definite histological characteristics of squamous cell carcinoma were demonstrated. Unfortunately, no further investigations for these cell lines after the initial reports have been conducted, nor has any attention been paid to the gene mutational events in the salivary gland adenoma-carcinoma sequence.

It is thus necessary to analyze the pathogenetic mode of the secondary onset of carcinomas in benign pleomorphic adenomas further in vitro, because most of the previous investigations have been limited to only surgical specimens and primary cultures. In the present study, our aim was to clone cell systems from a pleomorphic adenoma to characterize its transformed cells in various aspects. Since we were successful in establishing five cell systems after a long-period of primary culture from a benign pleomorphic adenoma, we analyzed these cells for cellular differentiation, chromosomal abnormality, p53 gene mutation, and histology of xenografted tumors in nude mice.

\section{Methods \\ Tumor sample}

A fresh tissue sample was obtained from a parotid gland tumor of a 61-year-old woman. The tumor, measuring 23 $\times 20 \times 15 \mathrm{~mm}$ in size, was surgically removed with tumorfree margins. The surgical material was fixed in $10 \%$ formalin, cut into about 3-5 mm thick slices using wholeorgan sectioning, and embedded in paraffin. Sections 5 $\mu \mathrm{m}$ thick were cut from the cut surfaces of the tumor specimens and stained with hematoxylin and eosin (HE). Macroscopically, the tumor was circumscribed with a 
fibrous capsule, and was grayish white in color, solid, firm and mucinous in its cut surface. There were no signs of local recurrence or metastasis during her three-year postoperative course. The experimental protocol for isolation and analyses of tumor cells was reviewed and approved by the Niigata University Graduate School of Medical and Dental Sciences Ethical Board. Prior to obtaining the tissue samples, our purpose and plan of the experiment were explained to the patient followed by her consent.

\section{Primary culture and cloning}

A tissue slice obtained from the central and maximum cut surface of the surgical material was minced into small pieces. The tissue pieces were treated with $0.1 \%(\mathrm{v} / \mathrm{w}) \mathrm{col}-$ lagenase (F. Hoffmann-La Roche Ltd., Basel, Switzerland) in Dulbecco's minimal essential medium (DMEM, Gibco, Invitrogen. Co., Carlsbad, CA, USA) containing 10\% fetal calf serum (Gibco), $50 \mathrm{IU} / \mathrm{ml}$ penicillin and $50 \mu \mathrm{g} / \mathrm{ml}$ streptomycin (Gibco) in a $2 \mathrm{ml}$ tube for $8 \mathrm{hrs}$ at $37^{\circ} \mathrm{C}$. Pass-through fractions from a nylon mesh filter were washed and plated in $2 \mathrm{ml}$ of DMEM in $35 \mathrm{~mm}$ dishes and incubated at $37^{\circ} \mathrm{C}$ in humidified $5 \%$ carbon dioxide/95\% air atmosphere. After two weeks, culture media were replaced with fresh ones and thereafter changed every 7 days. After one month, the cells, which had grown to confluence, were split into $25 \mathrm{~cm}^{2}$ flasks. When aggregates of polygonal and bizarre epithelioid cells appeared in the background of spindle-shaped cells in the fourth passage, the cells were split and thereafter passaged every week. After four passages, the cells were served for cloning. The cells prepared as above were plated in 96-well microplates using a conventional method of dilution [28]. Wells with a single cell were observed every $24 \mathrm{hrs}$ by microscope. The culture media were changed every 2 days. After the cells reached subconfluency in the wells, they were transferred into 24 well plates and maintained for up to 1 month until they reached subconfluent conditions, and then the cells were moved to $25 \mathrm{~cm}^{2}$ flasks.

\section{Immunohistochemistry}

All of the established cell systems were used for immunofluorescence studies. The cells were seeded at a cell concentration of $1.2 \times 10^{4}$ onto each well of chamber slides (Lab-Tek II, 4-well type, Nalge Nunc International, Naperville, IL, USA) and cultivated for 6 days. At day 6 after plating, the chamber slides were fixed and served for immunofluorescence experiments [29]. The primary antibodies consisted of rabbit polyclonal antibodies against human keratin (wide spectrum, Dako, Glostrup, Denmark, diluted at 1:25), and human S-100 protein (Dako, $1: 100)$ and mouse monoclonal antibodies against human cytokeratin (CK) 14 (clone CKB1, IgM, 1: 100, Sigma Chemical Co., St Louis, MO, USA), calpoinin (CALP1, $\operatorname{IgG}_{1}, 1: 50$, Dako), and P53 protein ( $\operatorname{IgG}_{2 a^{\prime}}$ specific to the transcription domain in the $\mathrm{NH}_{2}$-terminal region, clone
Bp53-11, Progen Bioteknik GmbH, Heidelberg, Germany). The secondary antibodies were rhodamine-conjugated goat anti-rabbit or mouse IgGs or IgM (ICN Pharmaceuticals, Aurora, OH, USA, 1:50). For control studies, purified non-immune rabbit IgG or mouse $\operatorname{IgG}_{2 a}$ (Dako) were used instead of the specific primary antibodies. Xenografts of pleomorphic adenoma cell systems in nude mice were also examined immunohistochemically for perlecan, a basement membrane type heparan sulfate proteoglycan, and fibronectin by using rabbit polyclonal antibodies (diluted at $50 \mu \mathrm{g} / \mathrm{ml}$, respectively) [29] and the rabbit Envision+/HRP system (Dako). For control studies on the antibodies, the primary antibodies were replaced with preimmune rabbit IgG.

\section{DNA Extraction}

Cellular DNAs were extracted from cells in primary culture and from all of the five established cell systems by using a TRIzol system (Invitrogen). The cells were cultivated for 7 days up to their subconfluency in $25 \mathrm{~cm}^{2}$ flasks, and $1 \mathrm{ml}$ of TRIzol reagent was added to each flask. Total RNAs were then extracted from the cell lysate according to the manufacturer's instructions. After complete removal of the aqueous RNA phase, DNA was isolated from the interphase and phenol-phase. Following precipitation with $0.1 \mathrm{M}$ sodium citrate in $10 \%$ ethanol, the precipitants were washed with $70 \%$ ethanol, and the pellets were air-dried briefly. The DNA samples dissolved in autoclaved water were stored at $-20^{\circ} \mathrm{C}$.

\section{Polymerase chain reaction (PCR)}

Exons 5-7 of the p53 gene were PCR amplified for sequencing to examine mutational events in cells in primary culture and all of the cloned cell systems. For exon 5 , a set of primers (forward, 5'-TTCAA CTCTG TCTCC TTCCT-3'; reverse, 5'-GACCT CTCTG CTGTC CCGAC-3') was used to generate a $323 \mathrm{bp}$ fragment. For exon 6 , a set of primers (forward, 5'-GCCTC TGATT CCTCA CTGAT-3'; reverse, 5'-AGAGA CCCTC CTCCC CAATT-3') was used for a 223 bp fragment. For exon 7, a set of primers (forward, 5'-CTTGC CACAG GTCTC CCCAA-3'; reverse, 5'CGGTG AACGG TGGGA CGTGT-3') was used for a 453 bp fragment. After first denaturation at $94^{\circ} \mathrm{C}$ for $4 \mathrm{~min}$, the experimental protocol for 35-cycle PCR was performed as follows: denaturation at $94^{\circ} \mathrm{C}$ for $1 \mathrm{~min}$, annealing at $60^{\circ} \mathrm{C}$ for $1 \mathrm{~min}$, extension at $72^{\circ} \mathrm{C}$ for $1 \mathrm{~min}$, and termination with a final extension at $72^{\circ} \mathrm{C}$ for $7 \mathrm{~min}$. Their sequence primer sets were from the nested primers used in the PCR experiments but with Texas red labeling at their 5 'ends.

\section{Direct sequencing of $P C R$ products}

All the PCR products for exons 5, 6 and 7 of the $p 53$ gene were subjected to direct sequencing by using Thermo Sequenase Primer Core Cycle Sequencing kits with 7 - 
deaza-dGTP (GE Healthcare Ltd./Amersham, Buckinghamshire, UK). One reaction mixture contained $3 \mu \mathrm{l}$ of pre-mixes (appropriate nucleotides/reaction buffer/ Thermo Sequenase DNA polymerase), $1 \mu \mathrm{l}$ of the template PCR products purified with GFX PCR DNA and Gel Band Purification kit (Amersham), and $2 \mu \mathrm{l}(2 \mathrm{pM})$ of Texas red-labeled primers. After denaturation at $95^{\circ} \mathrm{C}$ for $2 \mathrm{~min}$, the reaction mixture was placed on a thermal cycler for 25 cycles of denaturation at $95^{\circ} \mathrm{C}$ for $30 \mathrm{sec}$ and annealing/extension at $60^{\circ} \mathrm{C}$ for $30 \mathrm{sec}$. The reaction products were dissolved in $3 \mu \mathrm{l}$ loading buffer and concentrated with a vacuum desiccator. Then, $3 \mu \mathrm{l}$ of samples for each lane were loaded on a gel [7\% Long Ranger (Biowhittaker Molecular Applications, Rockland, ME, USA)/ $6.1 \mathrm{M}$ urea/1.2 $\times$ TBE buffer $(0.445 \mathrm{M}$ Tris-HCl, $0.445 \mathrm{M}$ boric acid, $0.01 \mathrm{M}$ EDTA)]. The electrophoresis was performed in a fluorescent DNA sequencer (SQ-5500-S, Hitachi Ltd., Tokyo, Japan) and the sequencing data were analyzed by using the SQ-5500 analysis software ver. 3.03 (Hitachi).

\section{Chromosomal analysis}

Primary culture cells in the fourth passages and all of the established cell systems in their subconfluent conditions were arrested for $3.5 \mathrm{hrs}$ with $0.06 \mu \mathrm{g} / \mathrm{ml}$ colcemid in DMEM. They were washed two times with PBS and then removed with $0.05 \%$ trypsin at $37^{\circ} \mathrm{C}$ for $5 \mathrm{~min}$. The cells were recovered from culture dishes with DMEM, suspended in $0.075 \mathrm{M} \mathrm{KCl}$ at $37^{\circ} \mathrm{C}$ for $30 \mathrm{~min}$ for hypotonic treatment, and then fixed in 1:3 acetic acid/methanol. The cell suspension was dropped onto glass slides to spread chromosomes from cells in the metaphase at room temperature under $50-55 \%$ ambient humidity. Slides were stained with $6 \%$ Giemsa solution in $0.067 \mathrm{M}$ phosphate buffer ( $\mathrm{pH}$ 6.8) for visualization of chromosomes. Metaphase spreads from 20 to 50 cells of the primary culture and each cell system were counted for chromosome numbers. Other slides were treated with $0.005 \%$ trypsin at $2{ }^{\circ} \mathrm{C}$ for $8 \mathrm{~min}$. They were washed and then stained with Giemsa solution for visualization of Giemsa (G)-banding. Ten to twenty cells each were analyzed for G-banded karyotypes in all of the cell systems. For control studies, peripheral blood lymphocytes from the patient were cultured in RPMI 1640 (Gibco) containing 10\% fetal calf serum (Gibco), $50 \mathrm{IU} / \mathrm{ml}$ penicillin and $50 \mu \mathrm{g} / \mathrm{ml}$ streptomycin (Gibco) for 3 days, and then analyzed for chromosome numbers and G-banded karyotypes in the same way as described above.

\section{Fluorescence in-situ hybridization (FISH) analysis of human bacterial artificial chromosome (BAC) clones} The genomic clones encoding the break point regions around $\mathrm{t}(9 ; 13)(\mathrm{p} 13 ; \mathrm{q} 12)$ were isolated from the $\mathrm{BAC}$ library [30] by the PCR screening method with primer sets flanking the regions of the two chromosomes by using the GenBank database http://www.ncbi.nlm.nih.gov/ as shown in Table 1. About $10 \mu \mathrm{l}$ of the DIG-labeled BAC DNA was mixed in $2 \mu \mathrm{l}$ of $10 \mathrm{mg} / \mathrm{ml}$ salmon sperm DNA (Roche), $2 \mu \mathrm{l}$ of $10 \mathrm{mg} / \mathrm{ml}$ E. coli tRNA (Roche), $4 \mu \mathrm{l}$ of 4 $\mathrm{M} \mathrm{CH}_{3} \mathrm{COONH}_{4}$, and $50 \mu \mathrm{l}$ of $100 \%$ ethanol. After storage for $1 \mathrm{hr}$ at $-80^{\circ} \mathrm{C}$, the mixture was melted and centrifuged in $8 \mu \mathrm{l}$ of the hybridization mixture consisting of $50 \%$ formamide, $10 \%$ dextran sulfate, $2 \times$ SSC solution for each slide. After $2 \mu \mathrm{l}$ of $10.5 \mathrm{mg} / \mathrm{ml}$ human placenta DNA (Sigma) was added, the mixtures were denatured for 10 min at $75^{\circ} \mathrm{C}$, cooled down, and supplemented with 1 $\mu \mathrm{BSA}$. The mixture was pre-annealed for $30 \mathrm{~min}$ at $37^{\circ} \mathrm{C}$ before applying it to the slides. Slide-bound chromosomal DNA was denatured in a solution of $70 \%$ formamide in $2 \times$ SSC for 6 min at $75^{\circ} \mathrm{C}$ on preheated slides for 2 hrs at $60^{\circ} \mathrm{C}$ and dehydrated in a $4^{\circ} \mathrm{C}$ ethanol series (70\% and 100\% ethanol for 5 min each). Ten microliters

Table I: BAC correlated with human data in the database and primer sequences for each BAC clone.

\begin{tabular}{|c|c|c|c|c|c|}
\hline \multirow[b]{2}{*}{ BAC clones } & \multicolumn{2}{|c|}{ Chromosomal location in human } & \multicolumn{3}{|c|}{ Primer } \\
\hline & & Accession number & Forward sequence & Reverse sequence & PCR-Product (bp) \\
\hline I537EI 2 & $9 p / 3.2$ & ALI6|445 & $\begin{array}{l}\text { TGCTTCTTGGAAATCAAGTCAA } \\
\text { AGGGTTAT }\end{array}$ & $\begin{array}{l}\text { CTGAATCTGGCACTTGGATTGT } \\
\text { CTCCATTC }\end{array}$ & 150 \\
\hline I405FI & $9 p / 3.1$ & ALI38834 & $\begin{array}{l}\text { TCAATGTCCCTTTGACCATTTC } \\
\text { CAAATTCA }\end{array}$ & $\begin{array}{l}\text { TTGAAGTCCACAGCTGCTGTGC } \\
\text { CTCTGAAA }\end{array}$ & 202 \\
\hline I529GII & $9 p / 2$ & ALI6|448 & $\begin{array}{l}\text { CCCTAAGAGGACCTGCAATTCT } \\
\text { TCCTTCAG }\end{array}$ & $\begin{array}{l}\text { GTTTTGTGGACCTTGAAGTGCT } \\
\text { ATATGGAA }\end{array}$ & 190 \\
\hline I01IG7 & $13 q 12.11$ & ALI6I772 & $\begin{array}{l}\text { ACTGGAGAGAATTTACTTTTAC } \\
\text { TTATGGTA }\end{array}$ & $\begin{array}{l}\text { TTGAGACTCACAGCCTGAAGG } \\
\text { GATAAACAC }\end{array}$ & 250 \\
\hline $2037 \mathrm{Cl}$ & $13 q 12.12$ & AL356287 & $\begin{array}{l}\text { CATTTCTTTGCCCTATAGACCT } \\
\text { GATTGAAA }\end{array}$ & $\begin{array}{l}\text { CTGTGCTCCCTTCATATAGCTT } \\
\text { GTCTTCCTA }\end{array}$ & 173 \\
\hline $1325 C 2$ & $13 q \mid 2.2$ & AL591024 & $\begin{array}{l}\text { GCAAAATCCAGGGGTAGAGCT } \\
\text { GAGTTGTGA }\end{array}$ & $\begin{array}{l}\text { CTGAGATGGATTCTGTATTTGC } \\
\text { CTATTTAC }\end{array}$ & 140 \\
\hline $1213 F 4$ & $13 q 13.1$ & $A L I 36160$ & $\begin{array}{l}\text { CATCAAATGCCGTTTGAAGATA } \\
\text { TGAAGATG }\end{array}$ & $\begin{array}{l}\text { TTTGGGAGCATCTTGACAGAAT } \\
\text { CCCTTTGA }\end{array}$ & 180 \\
\hline
\end{tabular}


of the hybridization mixture were applied to each slide, and the slides were sealed with cover glasses. After overnight incubation at $37^{\circ} \mathrm{C}$, the cover glasses were removed and the slides were washed once in $50 \%$ formamide $/ 2 \times$ SSC for $20 \mathrm{~min}$ at $37^{\circ} \mathrm{C}$ and twice in $2 \times$ SSC for $10 \mathrm{~min}$ at $37^{\circ} \mathrm{C}$, and then in TNT solution $(0.1 \mathrm{M}$ Tris- $\mathrm{HCl} / 0.15$ $\mathrm{M} \mathrm{NaCl} / 0.05 \%$ Tween 20) for $5 \mathrm{~min}$ at room temperature. The slides were further incubated with $100 \mu \mathrm{l}$ of TNB solution $(0.1 \mathrm{M}$ Tris-HCl/0.15 M NaCl/0.5\% blocking solution (Dainippon Pharmaceutical Co. Ltd., Osaka, Japan) to block non-specific reactions. The DIG-labeled probes were reacted with the anti-DIG mouse monoclonal antibody (Roche, $50 \mu \mathrm{l}$ of $1 \mu \mathrm{g} / \mathrm{ml} \mathrm{IgG} / 4 \times \mathrm{SSC}$ ) for $30 \mathrm{~min}$ at room temperature, rinsed three times in TNT solution for $5 \mathrm{~min}$, and then treated with the secondary antibody $(40$ $\mu \mathrm{l}$ of $10 \mu \mathrm{g} / \mathrm{ml}$ Alexa flour 488-conjugated goat antimouse IgG (Molecular Probes, Inc., Eugene, OR, USA)). Finally, the FISH slides were counterstained with $50 \mu \mathrm{g} /$ $\mathrm{ml}$ propidium iodide (PI, Vector Laboratories, Burlingame, CA, USA) for $30 \mathrm{~min}$ at room temperature. FISH images were obtained by an Olympus confocal laser scanning microscope Fluoroview 1000 (Olympus Co., Tokyo, Japan).

\section{Xenografts in nude mice}

To determine in vivo tumorigenicities of the cloned cell systems, SM-AP cells were transplanted in nude mice. Cells in their 9th to 13th in vitro passages at a concentration of $2 \times 10^{6}$ in $0.3 \mathrm{ml}$ culture media were injected into the lateral back wall of female BALB/c (nu/nu) mice at 4 weeks of age ( 2 mice each per cell system). The animals were housed in clean boxes in a sanitary and ventilated animal room and maintained under constant conditions (at $22^{\circ} \mathrm{C}$ and in a 12-hr light/dark cycle) with free access to sterilized solid food and autoclaved water. When tumors reached sizes of around $10-15 \mathrm{~mm}$ in diameter, they were surgically removed with the animals under ether anesthesia. The excised tumor tissues were fixed in $10 \%$ formalin for $24 \mathrm{hrs}$ at $4{ }^{\circ} \mathrm{C}$ and embedded in paraffin. Serial sections cut at $5 \mu \mathrm{m}$ from the paraffin blocks were stained with hematoxylin and eosin, Masson's trichrome and immunoperoxidase for perlecan, fibronectin, keratin, S-100 and P53, and then examined histologically. The experimental research by using animals was reviewed and approved by the Niigata University Graduate School of Medical and Dental Sciences Ethical Board.

\section{Results}

\section{Tissue sample histology}

The surgical specimen of the parotid gland tumor showed a typical histology of pleomorphic adenoma with a definite capsule (Figure 1A). The tumor contained both myxoid and hyaline areas with varied cellularity but poor vascularity. There were neither apparent foci of carcinoma cells nor pleomorphic adenoma cells with apparent atypical features (Figure 1B).

\section{Establishment of pleomorphic adenoma cell systems}

For the first to third cell passages of the primary culture, it took about 2 months for each of the cells to form a confluent monolayer in a $25 \mathrm{~cm}^{2}$ flask ready for splitting. During the period up to the third passage, cells were almost spindle-shaped in isolated colonies but did not show any fascicular modes of packing as seen in fibroblasts (Figure 1C). At the fourth passage, clusters of polygonal cells with ground glass-like cytoplasm started to appear among the spindle-shaped cells (Figure 1D), and the cells reached confluence in 7 days. After four additional passages, during which polygonal cells became enhanced in their atypical features in size and shape of their nuclei and such bizarre cells increased in number in most of the colonies, these cells were served for cloning. From serial dilutions in 96-well microplates, single cells were isolated in individual wells and grew to confluence within one month after plating. They were transferred into 24-well plates and then to a $25 \mathrm{~cm}^{2}$ flask. These cloning procedures were repeated twice, and finally, 5 clones were successfully grown from the primary culture. They were designated as SM-AP1 to SM-AP5. After the cloning procedure, the five cloned cell systems were maintained by passages every 7 days. Their doubling times were approximately 31 hrs irrespective of the five cell systems. They were classified into two groups according to their cell shapes: one was polygonal with squamous epithelial characteristics, which was shared by SM-AP1 (Figure 1E), SM$\mathrm{AP} 2$, and $\mathrm{SM}-\mathrm{AP} 3$, and the other was short spindle shaped, which was characteristic of SM-AP4 and SM-AP5 (Figure 1F).

\section{Immunofluorescence of clones SM-AP cell systems}

Clones SM-AP1 to SM-AP5 were stained positive for keratin, a duct-epithelial marker (Figures 2A-2D). SM-AP1, SM-AP2, and SM-AP3 cells were not positive for S-100 protein, a myoepithelial marker (Figures 2C), while SMAP4 and SM-AP5 cells were strongly positive (Figures 2D) mainly in their nuclei. In addition to S-100 protein, SMAP4 and SM-AP5 were positive for such myoepithelial markers as CK14 and calponin. All primary cultured cells and five cell systems showed immunopositivities for perlecan but none for P53 protein (not shown).

\section{Chromosome analysis}

Chromosome numbers of the five cell systems varied between 64 and 123, which were within tetraploid or pentaploid ranges, with a modal chromosome number of 108 (Figure 3A-a-e). Chromosome numbers of primary cultured cells varied between 107 and 122 with a modal chromosome number of 113 (Figure 3A-f). The G-banded karyotyping revealed a stemline karyotype of 

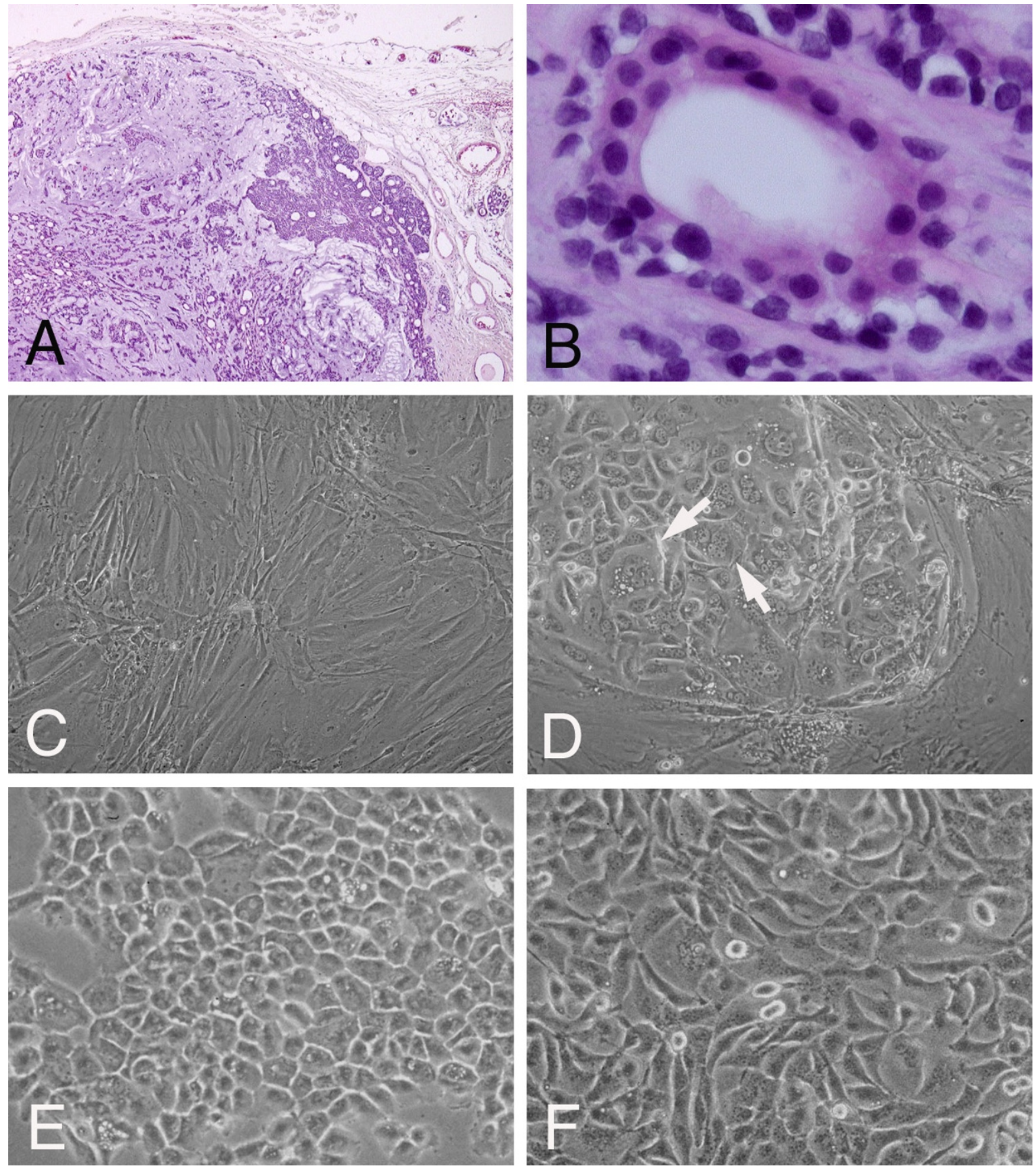

Figure I (see legend on next page) 
Figure I (see previous page)

Histopathology of pleomorphic adenoma from which cells were isolated (A, HE stain, $\times 40 ; B, H E$ stain, $\times 200$ ) and phase-contrast microscopy of pleomorphic adenoma cells (C, primary culture, $\times 100$; D, colony with bizarre cells, × I35; E, established cell system SM-AP3, x I 50; F, SM-AP5, x I 50). The surgical specimen showed typical features of benign pleomorphic adenoma (A), containing only a small number of atypical tumor cells (B). Cells in the primary culture were mainly spindle in shape mixed with fewer amounts of polygonal cells $(\mathbf{C})$. In the fourth passage, aggregates of polygonal and bizarre epithelioid cells appeared in the background of spindle-shaped cells (D). From the following passage, five clones were successfully grown and isolated. They were classified into two groups according to their cell shapes. One was a polygonal shape represented by SM-AP3 (E), and the other was a short spindle shape one as shown by SM-AP5 (F).
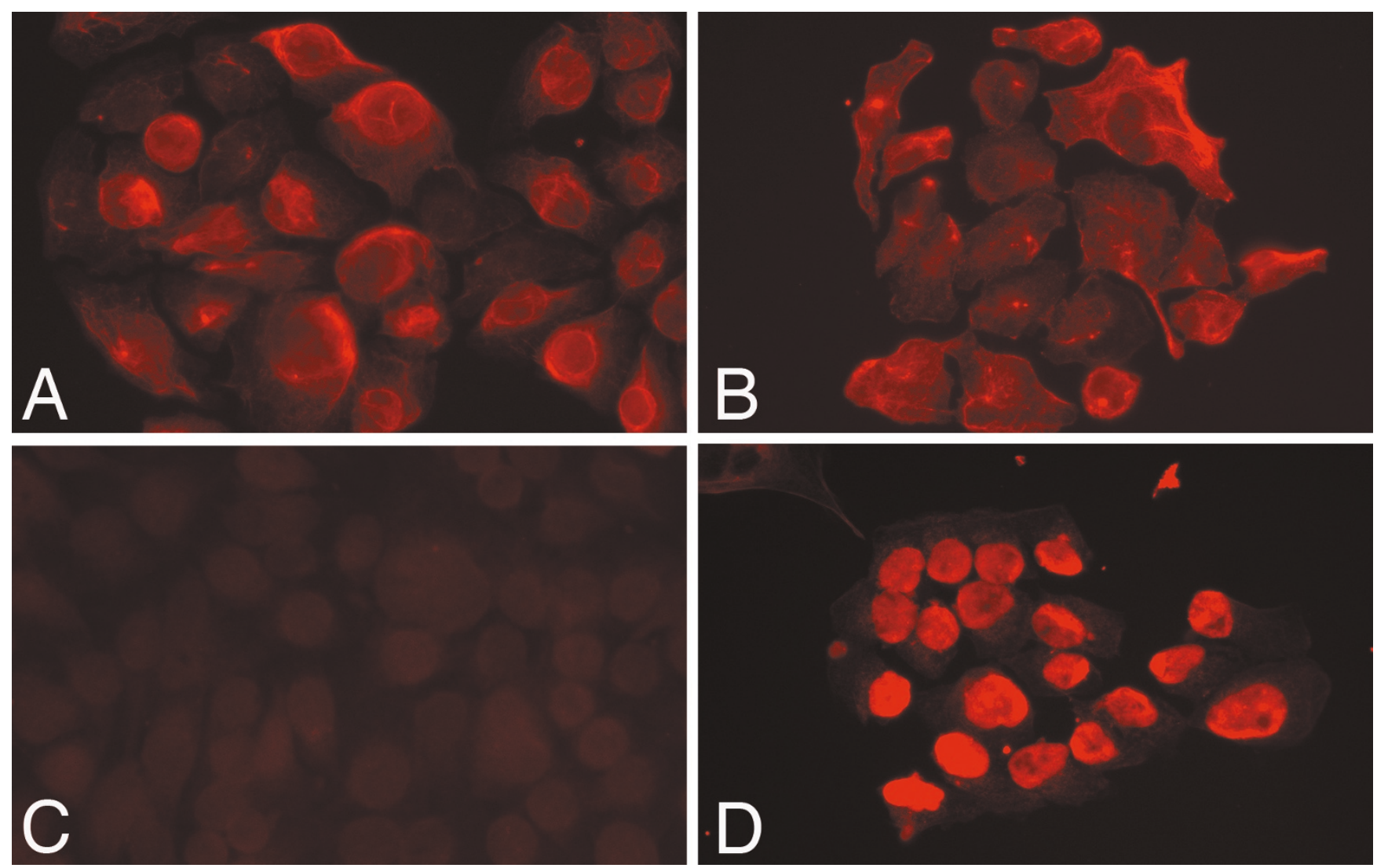

Figure 2

Immunohistochemistry for keratin, duct epithelial marker (A-B) and S- 100 protein, myoepithelial marker (CD) in pleomorphic adenoma cell systems: SM-API (A, C), SM-AP4 (B, D) at day 6 after plating, indirect immunofluorescence, $\times \mathbf{2 0 0}$. All of the cell systems, SM-API to SM-AP5, were equally immunopositive for keratin (A-B). SM-API, SM-AP2, and SM-AP3 cells were not definitely positive for S-100 protein (C), while SM-AP4 and SM-AP5 cells were strongly positive for S-I00 protein (D). 
A
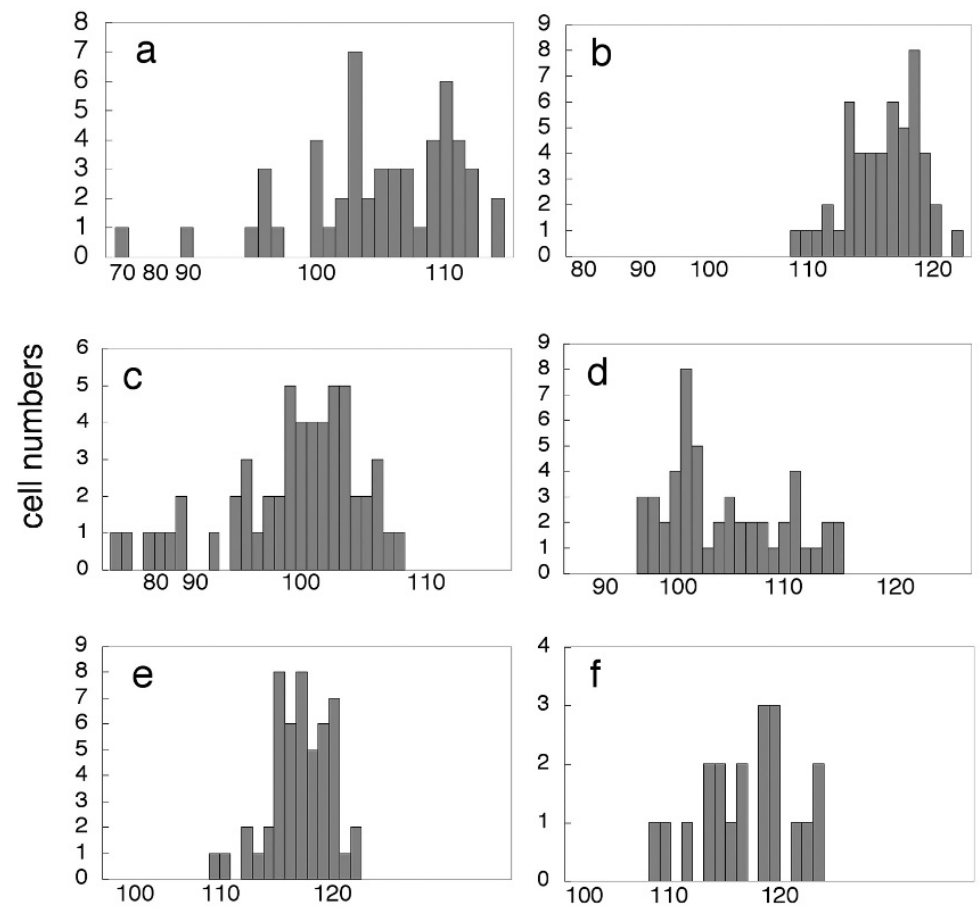

chromosome numbers

B

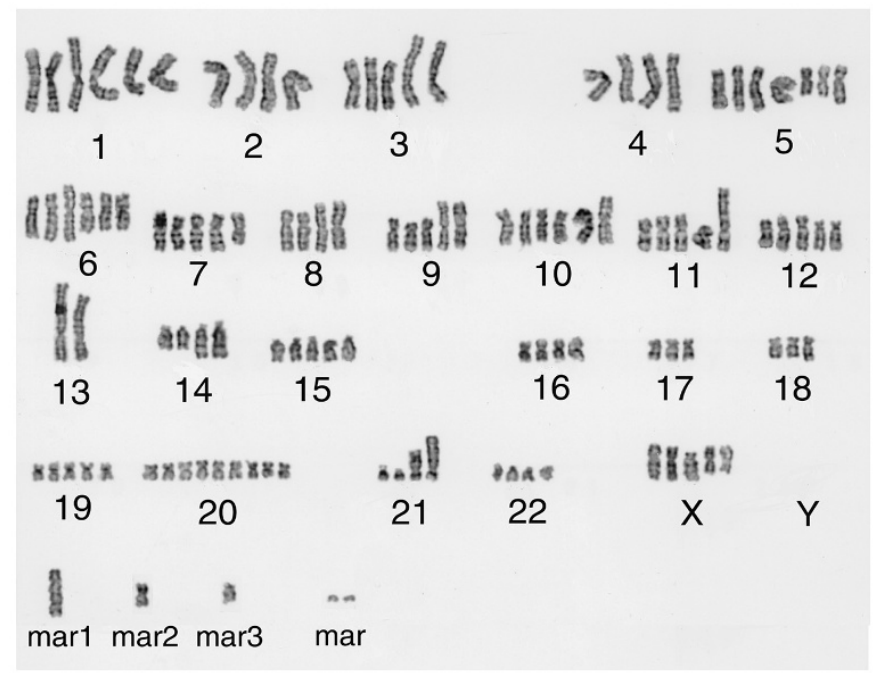

\section{Figure 3}

Cytogenetic analysis of pleomorphic adenoma cell systems. Panel A, chromosome numbers of pleomorphic adenoma cell systems: SM-API (a), SM-AP2 (b), SM-AP3 (c), SM-AP4 (d), SM-AP5 (e), and those of cells in the primary culture (f) in histograms. Panel B, G-banded karyotyping of SM-AP5. Chromosome numbers of the five cell systems varied between 64 and 123, which were within tetraploid or pentaploid ranges, with a modal chromosome number of 108 . Those of primary culture varied between 107 and 122 with a modal of II 3 . 
Table 2: Chromosome counts and stemline karyotyps of pleomorphic adenoma cell systems.

\begin{tabular}{|c|c|c|c|}
\hline \multirow[b]{2}{*}{ cell systems } & \multirow[b]{2}{*}{ Cell numbers counted/karyotyped } & \multicolumn{2}{|r|}{ stemline karyotypes } \\
\hline & & Chromosome numbers <ploidy $>$ & chromosomal abnomalities \\
\hline \multirow[t]{9}{*}{ SM-API } & $50 / 10$ & $70-114<5 n>$ & $\begin{array}{l}X X,-X[6],-X[3], \operatorname{add}(X)(p \mid I)[I 0], \operatorname{add}(X)[5], \\
\operatorname{add}(X)(q \mid l)[7],+I[7], \operatorname{add}(I)(p \mid I) \times 2[I 0], \operatorname{add}(I)(q I I)[I 0],\end{array}$ \\
\hline & & & $\begin{array}{l}\operatorname{add}(1)[9],-2[10],-2[10],+3[2],-3[5] \\
\operatorname{der}(3) \operatorname{add}(3)(\mathrm{pl}) \operatorname{del}(3)(\mathrm{q} 2 ?)[10], \operatorname{der}(3) \operatorname{add}(3) \operatorname{del}(3)[5]\end{array}$ \\
\hline & & & $\begin{array}{l}\operatorname{der}(3) \operatorname{add}(3) \operatorname{del}(3)[2],-4[9], \operatorname{add}(4)(p \mid l)[2], \operatorname{add}(4)(\mathrm{q} 35)[10], \\
\operatorname{add}(4)[8],+5[2], \operatorname{add}(5)(q \mid \mathrm{I})[10], \operatorname{add}(5)[6],\end{array}$ \\
\hline & & & $\begin{array}{l}-6[9],-6[6], \text { add }(6)(q \mid 1)[8],-8[6], i(8)(q \mid 0)[10], i(8)[7],-9[3], \\
\operatorname{der}(9) t(9 ; \mid 3)(p|3 ; q| 2) \times 2[10],-10[5],\end{array}$ \\
\hline & & & $\begin{array}{l}\mathrm{i}(10)(\mathrm{q} \mid 0)[9],-1 \mid[5], \operatorname{add}(11)(\mathrm{p} \mid 5)[9],+12[8] \\
\operatorname{add}(12)(\mathrm{p} \mid \mathrm{I}) \times 2[10], \operatorname{add}(12)[9],-13[10],-13[10],-13[4]\end{array}$ \\
\hline & & & $\begin{array}{l}\operatorname{add}(13)(\mathrm{p} \mid 1)[10], \operatorname{add}(13)[4],-14[8],-14[3] \\
\operatorname{add}(14)(q 32)[10], \operatorname{add}(14)[9],+15[6],+16[2],-16[3]\end{array}$ \\
\hline & & & $\begin{array}{l}\text { add(16)(q2!2)[10], add(16)[3], - } 17[4], \text { del}(\mid 7)(p \mid I)[8],- \\
\mid 8[9], \text { add }(18)(q \mid 1)[8],+19[8],+19[2],+20[8],\end{array}$ \\
\hline & & & $\begin{array}{l}+20[8],+2 \mid[I 0], \text { add }(2 I)(p \mid l)[8], \text { add(2I)(pII)[5], } \\
\operatorname{der}(2 \mid) t(\mid 3 ; 2 I)(q|I ; p| I)[7],-22[\mid 0],-22[9],-22[6]\end{array}$ \\
\hline & & & $\begin{array}{l}+\operatorname{mar} 1[9],+\operatorname{mar} 2[10],+\operatorname{mar} 2[5],+\operatorname{mar} 3[4],+\operatorname{mar} 5[2], \\
+04 \text { mar. }\end{array}$ \\
\hline
\end{tabular}

SM-AP2 $50 / 10 \quad 108-123<5 n>$
$X X,-X[6], \operatorname{add}(X)(p \mid I)[I 0], \operatorname{add}(X)[6], \operatorname{add}(X)(q \mid I)[7]$, $\operatorname{add}(X)[2],+1[8],+1[2]$, add $(I)(P I I) \times 2[10]$, $\operatorname{add}(I)(p \mid l)[2], \operatorname{add}(I)(q \mid I)[I 0], \operatorname{add}(I)[7],-2[5]$, $\operatorname{add}(2)(\mathrm{plI})[7], \operatorname{idic}(2)(\mathrm{q} 23)[7],-3[3]$,
$\operatorname{der}(3) \operatorname{add}(3)(\mathrm{pl} \mathrm{I}) \operatorname{del}(3)(\mathrm{q} 2$ ?)[10], $\operatorname{der}(3) \operatorname{add}(3) \operatorname{del}(3)[6],-$ $4[7]$, add (4)(q35) $\times 2[10],+5[5], \operatorname{add}(5)(q 11)[9]$, $\operatorname{add}(5)[4],+6[3], \operatorname{add}(6)(q \mid 1)[9], \operatorname{del}(6)(q 25)[3],-8[9]$, $\mathrm{i}(8)(\mathrm{q} / 0) \times 2[10],+9[2],-9[3]$, $\operatorname{der}(9) \mathrm{t}(9 ; 13)(\mathrm{p}|3 ; q| 2)[10], \operatorname{der}(9) \mathrm{t}(9 ; 13)[8],+10[7],+10[4]$, $\operatorname{add}(10)(p \mid \mathrm{I})[4], \mathrm{i}(10)(\mathrm{q} \mid 0)[10], \mathrm{i}(10)[7]$, $\operatorname{add}(\mathrm{II})(\mathrm{PII})[9], \operatorname{add}(\mathrm{II})(\mathrm{pI})[\mathrm{IO}],+\mathrm{I}$ [7], $\operatorname{add}(12)(\mathrm{pl} \mid) \times 2[10]$, add(I2)[8], - I3[10], - I3[10], -13[10], $-13[3]$, add(13)(pII)[10], add(13)[5], - I4[7], $\operatorname{add}(14)(q 32) \times 2[10],+15[6],-16[5], \operatorname{add}(16)(q 2$ ?2)[8], - 17[6], $\operatorname{del}(\mid 7)(\mathrm{plI})[4],-\mid 8[8]$, add(I8)(qII)[8], add(I8)(q2I)[2], $\operatorname{add}(18)(q 23)[5],+19[7],+20[9],+20[3],-2 \mid$ [8], $\operatorname{add}(2 \mathrm{l})(\mathrm{pl} \mathrm{l})[9]$, add(2l)(pl I)[I0], add(2l)(pl I)[3], -22[I0], $-22[4]$,
$+\operatorname{mar} 1$ [8], +mar2[10], +mar2[2], +mar3 × 2[10], +mar4[2], +07 mar.

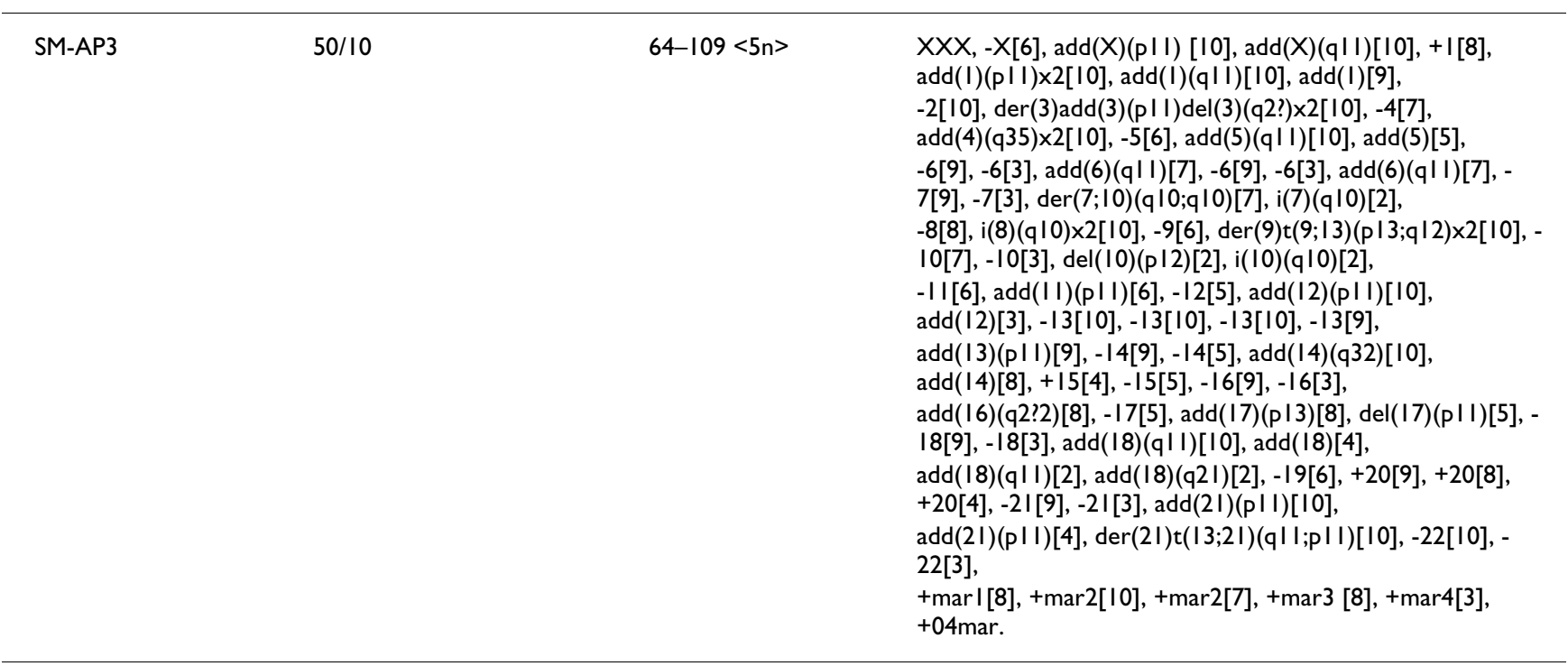


Table 2: Chromosome counts and stemline karyotyps of pleomorphic adenoma cell systems. (Continued)

\begin{tabular}{|c|c|c|c|}
\hline \multirow[t]{10}{*}{ SM-AP4 } & $50 / 10$ & $97-115<5 n>$ & $\begin{array}{l}X X,-X[8], \text { add }(X)(p \mid I)[10], \text { add }(X)(q \mid I)[9], \text { add }(X)[2], \\
+\mid[2], \text { add }(I)(p \mid I)[9], \text { add }(I)[3],\end{array}$ \\
\hline & & & $\begin{array}{l}\operatorname{add}(I)(q \mid l) \times 2[10],-2[9],-3[7], \\
\operatorname{der}(3) \operatorname{add}(3)(p \mid I) \operatorname{del}(3)(q 2 ?) \times 2[10], \operatorname{der}(3) \operatorname{add}(3) \operatorname{del}(3)[3],- \\
4[10],\end{array}$ \\
\hline & & & $\begin{array}{l}\operatorname{add}(4)(\mathrm{q} 35)[10], \operatorname{add}(4)[9],+5[2],-5[5], \operatorname{add}(5)(\mathrm{q} \mid \mathrm{I})[10] \\
\operatorname{add}(5)[3],-6[7], \operatorname{add}(6)(\mathrm{pl})[5],\end{array}$ \\
\hline & & & $\begin{array}{l}\operatorname{add}(6)(q \mid \mathrm{l})[10], \operatorname{add}(6)[5],+7[3], \operatorname{add}(7)(\mathrm{q} \mid \mathrm{I})[4],-8[6], \\
\mathrm{i}(8)(\mathrm{q} \mid 0)[10], \mathrm{i}(8)[8],-9[5],\end{array}$ \\
\hline & & & $\begin{array}{l}\operatorname{der}(9) \mathrm{t}(9 ; 13)(\mathrm{p}|3 ; \mathrm{q}| 2)[10], \operatorname{der}(9) \mathrm{t}(9 ; \mid 3)[7],-10[6] \\
\mathrm{i}(10)(\mathrm{q} \mid 0)[9], \mathrm{i}(10)[2],-1 \mid[7], \operatorname{add}(12)(\mathrm{p} \mid \mathrm{I}) \times 2[10]\end{array}$ \\
\hline & & & $\begin{array}{l}-13[10],-13[10],-13[10],-13[4], \operatorname{add}(13)(\mathrm{pII})[7], \operatorname{add}(13)[2], \\
\operatorname{add}(13)(\mathrm{pII})[2],-14[9], \operatorname{add}(\mid 4)(\mathrm{q} 32)[10],\end{array}$ \\
\hline & & & $\begin{array}{l}\operatorname{add}(14)[9], \operatorname{der}(14) \mathrm{t}(1 ; 14)(\mathrm{q}|1 ; \mathrm{p}| 1),-16[7],-16[3], \\
\operatorname{add}(16)(\mathrm{q} 2 ? 2)[7], \operatorname{add}(16)[2],-17[10],-17[8],-18[10]\end{array}$ \\
\hline & & & $\begin{array}{l}-18[7], \text { add }(18)(q \mid I)[9], \text { add }(I 8)[2],+19[5],+20[10],+20[9], \\
+20[6],-2|[\mid 0],-2|[6], \text { add }(2 \mid)(p \mid I)[9],\end{array}$ \\
\hline & & & $\begin{array}{l}\operatorname{add}(2 \mid)(p \mid I)[2], \operatorname{der}(2 I) t(|3 ; 2|)(q|I ; p| I)[9],-22[\mid 0],- \\
22[3],\end{array}$ \\
\hline & & & $\begin{array}{l}+\operatorname{mar} 1[7],+\operatorname{mar} 2[8],+\operatorname{mar} 3[7],+\operatorname{mar} 4[3],+\operatorname{mar} 5[2] \\
+03 \text { mar. }\end{array}$ \\
\hline \multirow[t]{11}{*}{ SM-AP5 } & $50 / 10$ & $109-122<5 n>$ & $\begin{array}{l}X X,+\operatorname{add}(X)(q \mid I)[4], \operatorname{add}(X)[9], \operatorname{add}(X)(p \mid I)[\mid 0] \\
\operatorname{add}(X)[9],+|[\mid 0],+|[3], \operatorname{add}(I)(p \mid I)[2]\end{array}$ \\
\hline & & & $\begin{array}{l}\text { add }(I)(p \mid I) \times 2[I 0], \text { add }(I)(q \mid I)[I 0], \text { add }(I)[8], i(I)(q \mid 0)[3],- \\
2[I 0],-2[7],-3[4] \text {, }\end{array}$ \\
\hline & & & $\begin{array}{l}\operatorname{der}(3) \operatorname{add}(3)(p \mid I) \operatorname{del}(3)(q 2 ?)[10], \operatorname{der}(3) \operatorname{add}(3) \operatorname{del}(3)[3] \\
\operatorname{der}(3) \operatorname{add}(3)(p \mid \mathrm{I}) \operatorname{del}(3)(q 2 ?)[2],-4[10]\end{array}$ \\
\hline & & & $\begin{array}{l}\operatorname{add}(4)(q 35) \times 2[10],+5[9], \operatorname{add}(5)(q 11) \times 2[10],-6[8] \\
\operatorname{add}(6)(q 11)[10], \operatorname{add}(6)[2],-8[6], \mathrm{i}(8)(\mathrm{q} \mid 0) \times 2[10]\end{array}$ \\
\hline & & & $\begin{array}{l}\mathrm{i}(8)[3],+9[3], \operatorname{add}(9)(\mathrm{p} \mid \mathrm{I})[5], \operatorname{der}(9) \mathrm{t}(9 ; 13)(\mathrm{p}|3 ; \mathrm{q}| 2)[10], \\
\operatorname{der}(9) \mathrm{t}(9 ; 13)[9],+10[10], \mathrm{i}(10)(\mathrm{q} \mid 0) \times 2[10],\end{array}$ \\
\hline & & & $\begin{array}{l}-11[3], \operatorname{add}(1 \mathrm{I})(\mathrm{p} \mid 5) \times 2[10], \operatorname{add}(1 \mathrm{I})[5],+12[5], \\
\operatorname{add}(12)(\mathrm{p} \mid \mathrm{I}) \times 2[10], \operatorname{add}(12)[5],-13[10],-13[10],-13[9]\end{array}$ \\
\hline & & & $\begin{array}{l}\operatorname{add}(13)(\mathrm{pl} \mid) \times 2[10],-\mid 4[10], \operatorname{add}(14)(\mathrm{pl} \mid)[3] \\
\operatorname{add}(14)(\mathrm{pl} \mid)[4], \operatorname{add}(14)(\mathrm{q} 32)[10], \operatorname{add}(14)[9],+\mid 5[5]\end{array}$ \\
\hline & & & $\begin{array}{l}+16[3], \operatorname{add}(16)(q 2 ? 2)[10], \operatorname{add}(16)[7],-17[8],-17[3], \\
\operatorname{del}(17)(\mathrm{plI})[3],-18[9]\end{array}$ \\
\hline & & & $\begin{array}{l}-18[3], \text { add }(18)(\mathrm{q} \mid 1)[6], \text { add }(18)(\mathrm{q} 23)[6], \operatorname{del}(18)(\mathrm{q} 21)[2] \\
+19[10],+19[3],+20[10],+20[10],+20[2]\end{array}$ \\
\hline & & & $\begin{array}{l}-2 \mid[8], \operatorname{add}(2 \mathrm{I})(\mathrm{pI} \mathrm{I})[\mathrm{I} 0], \operatorname{add}(2 \mathrm{I})(\mathrm{pI} \mathrm{I})[2],-22[9],-22[7],- \\
22[3],\end{array}$ \\
\hline & & & $\begin{array}{l}+\operatorname{mar} 1[9],+\operatorname{mar} 2[10],+\operatorname{mar} 2[6],+\operatorname{mar} 3[8],+\operatorname{mar} 3[6] \\
+\operatorname{mar} 5[2],+06 \text { mar. }\end{array}$ \\
\hline \multirow[t]{6}{*}{ Primary } & $20 / 20$ & $107-122<5 n>$ & $\begin{array}{l}X X,-X,-X,-X, \text { add }(I)(p \mid I) \text {, add }(I)(q ? \mid 2) \times 2,-2,-3,-3, \\
\operatorname{add}(4)(q 3 I .3) \times 2,+5\end{array}$ \\
\hline & & & $\begin{array}{l}\operatorname{der}(5) \operatorname{add}(5)(p \mid 5.1) \operatorname{add}(5)(q 22) \times 2,-6, \operatorname{add}(6)(q 21) \times 2 \\
+\operatorname{add}(7)(q \mid I .2) \times 2, i(8)(q \mid 0) \times 2,\end{array}$ \\
\hline & & & $\begin{array}{l}-9, \operatorname{add}(9)(p \mid I), \operatorname{der}(9) t(9 ; \mid 3)(p|3 ; q| 2) \times 2,+10 \\
\operatorname{add}(\mid 0)(p|| . \mid), i(\mid 0)(q \mid 0) \times 2,+1 \mid,\end{array}$ \\
\hline & & & $\begin{array}{l}\text { add }(\mid 1)(p|| .2), \text { add }(\mid 1)(p \mid 5),+12,+12, \text { add }(\mid 2)(p|| .2) \times 4,- \\
|3,-| 3,-\mid 3,-13,-14,\end{array}$ \\
\hline & & & $\begin{array}{l}\operatorname{add}(14)(q ? 24) \times 2,+15, \operatorname{add}(16)(q ? \mid 2.1),-17, ? \\
\operatorname{add}(17)(p \mid 1.2) \times 2,-18,-18,+19,+20,\end{array}$ \\
\hline & & & $\begin{array}{l}-21,-21,-21,-22,+\operatorname{mar} 1 \times 2,+\operatorname{mar} 2 \times 2,+\operatorname{mar} 3 \times 2,+\operatorname{mar} 4 \\
\times 2,+\operatorname{mar} 5 \times 2[\text { cp } 20]\end{array}$ \\
\hline
\end{tabular}


$102 \sim 114<5 \mathrm{n}>$, XX in SM-AP1; $113 \sim 121<5 \mathrm{n}>$, XX in SMAP2; 98 108<5n>, XXX in SM-AP3; 97 115<5n>, XX, in SM-AP4; 114 121<5n>, XX in SM-AP5. Figure 3B represents the SM-AP5 stemline karyotype. All of the cell systems had numerous chromosomal abnormalities, such as deletion, translocation and marker chromosomes as shown in Table 2. Among them, additional materials of unknown origin such as $\operatorname{add}(\mathrm{X})(\mathrm{p} 11)$, der(3) add(3)(p11)der(3)(q2?), add(4)(q35) and translocations such as $\operatorname{der}(9) \mathrm{t}(9 ; 13)(\mathrm{p} 13 ; \mathrm{q} 12)$, add(12)(p11), and add(14)(q32) were shared by all of them. Since the $\operatorname{der}(9) \mathrm{t}(9 ; 13)(\mathrm{p} 13 ; \mathrm{q} 12)$ was the only abnormality in which the origin of translocated chromosomes was evident, this translocation was further analyzed for its break points by the FISH technique as described below. Chromosome 17, where the p53 gene is located at p13, decreased in number in all of the cell systems. In addition, del(17)(p11) was shared by four cell systems except for SM-AP4. SM-AP3 cells had add(17)(p13), which might have affected the $p 53$ gene locus.

Primary cultured cells shared the same translocations as those of the established SM-AP cell systems, such as $\operatorname{der}(9) \mathrm{t}(9 ; 13)(\mathrm{p} 13 ; \mathrm{q} 12)$ and $\operatorname{add}(12)(\mathrm{p} 11)$ (Table 2). Peripheral blood lymphocytes from the patient had normal chromosome numbers and karyotype (not shown).

\section{Screening of chromosomal break points for translocation $t(9 ; 13)(p / 3 ; q / 2)$}

To restrict the break points for the translocation $\mathrm{t}(9 ; 13)(\mathrm{p} 13 ; \mathrm{q} 12)$, which was shared by all five cell systems, FISH analyses for chromosome 9p13 and $13 q 12$ regions were performed. By using the primer sets listed in Table 1, three clones for chromosome 9 (p13) and four clones for chromosome 13 (q12) were isolated by PCR to map their chromosomal locations. Clear single or paired FISH signals were demonstrated by the BAC clones, 1537E12 (Figure 4A-b) and 1405F1 (Figure 4A-c), which are located in chromosome 9p13.2 and 9p13.1, respectively (Figure 4A-a). BAC clones by $1325 \mathrm{C} 2$ in chromosome 13q12.2 (Figure 4B-a) were localized on chromosomes with translocation $\mathrm{t}(9 ; 13)(\mathrm{p} 13 ; \mathrm{q} 12)$ (Figure $4 \mathrm{~B}-\mathrm{c})$. FISH signals for $1213 \mathrm{~F} 4$, which is located in chromosome $13 q 13.1$, were not found on any chromosomes (Figure 4B-b). Thus, break points for the translocation, $\mathrm{t}(9 ; 13)(\mathrm{p} 13 ; \mathrm{q} 12)$, were thought to be located in restricted regions of $9 \mathrm{p} 13.3$ and $13 \mathrm{q} 12.3$.

\section{P53 gene analysis}

PCR amplicons for exons 5, 6 and 7 of the $p 53$ genes from the primary cultured cells as well as from all of the SM-AP cell systems were sequenced, and deletion of the last base G of codon \#249 (AGG to AG_) of exon 7 was found in all of them including the primary culture (Figure 5). Owing to this point mutation, a nonsense polypeptide should have been generated on and after codon \#249, resulting in non-functional $p 53$ gene products. No other mutations were found in exons 5 and 6 .

\section{Xenografts of SM-AP cells in nude mice}

Five cell systems, SM-AP1 to SM-AP5, successfully formed subcutaneous tumors in nude mice after 5 to 19 weeks of injections (Figure 6A, Table 3). The tumors which had grown to 10 to $15 \mathrm{~mm}$ in diameter were harvested for histopathological examinations (Figure 6B). Histologically, transplanted tumors showed rather expansive growths mostly limited to the range of the dermis to the subcutis or to only the surface part of the muscle layer, although they had no definite fibrous capsules. Tumor cell nests varied in size, and some of them contained keratinization centers, irrespective of transplanted tumors. Hence, squamous cell carcinomas were basically diagnosed for all of the tumors formed by the five cell systems. However, their keratinization seemed to occur suddenly without gradual differentiation tendencies in the tumor cell nests, which had no basal cell alignment at the periphery of the tumor cell nests (Figure 6C), which were usually not seen in squamous cell carcinomas of the oral mucosal origin. In the transplanted tumors of SM-AP1 to SM-AP3, which had been regarded as duct-epithelial by immunofluorescence in vitro, there were tendencies to form mimics of ductal structures (Figure 6D, arrow). Those of SM-AP1 and SMAP2 contained tumor cells with plasmacytoid appearances (Figure 6E). In those of SM-AP4 and SM-AP5, which had rather myoepithelial natures in vitro, tumor cell nests were sheet-like with some tendencies toward keratinization, and they showed ground glass-like cytoplasm (Figure $6 \mathrm{~F}$ ). Mitotic figures were observed in each tumor but more frequently in SM-AP4 and SM-AP5 (Figure 6G, arrows), suggestive of their malignant natures. Hyaline stromal spaces without definite vascular channels and lymphocytic infiltration were formed between tumor cell nests in every tumor, which were also unusual in oral squamous cell carcinomas (Figure 6H). Immunohistochemically, the hyaline stroma was strongly positive for perlecan (Figure 6I) as well as for fibronectin (Figure 6J). Although there was no area with a typical histology of benign pleomorphic adenoma in the transplanted tumors, the presence of ductal mimics, plasmacytoid cells, ground-glass appearance of tumor cell cytoplasm and predominant hyaline stroma mentioned above might indicate their pleomorphic adenoma origin. However, there were no foci of salivary duct carcinoma, which is common in carcinoma ex pleomorphic adenoma. Immunohistochemically, the transplanted tumors of SM-AP1 to SMAP5 were stained positive for keratin. SM-AP1, SM-AP2, and SM-AP3 cells were not positive for S-100 protein, while SM-AP4 and SM-AP5 cells were strongly positive for other myoepithelial markers, such as CK14 and calponin, in addition to $\mathrm{S}-100$ protein. All five transplanted cell sys- 
A
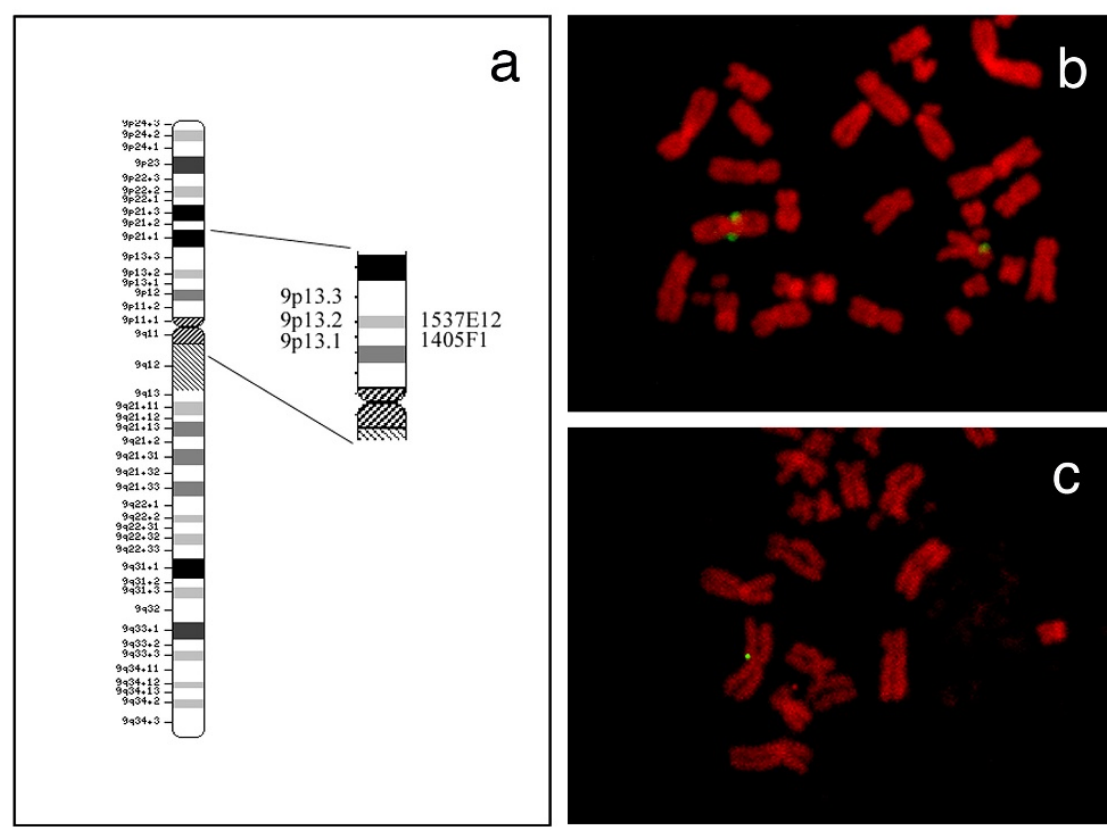

B
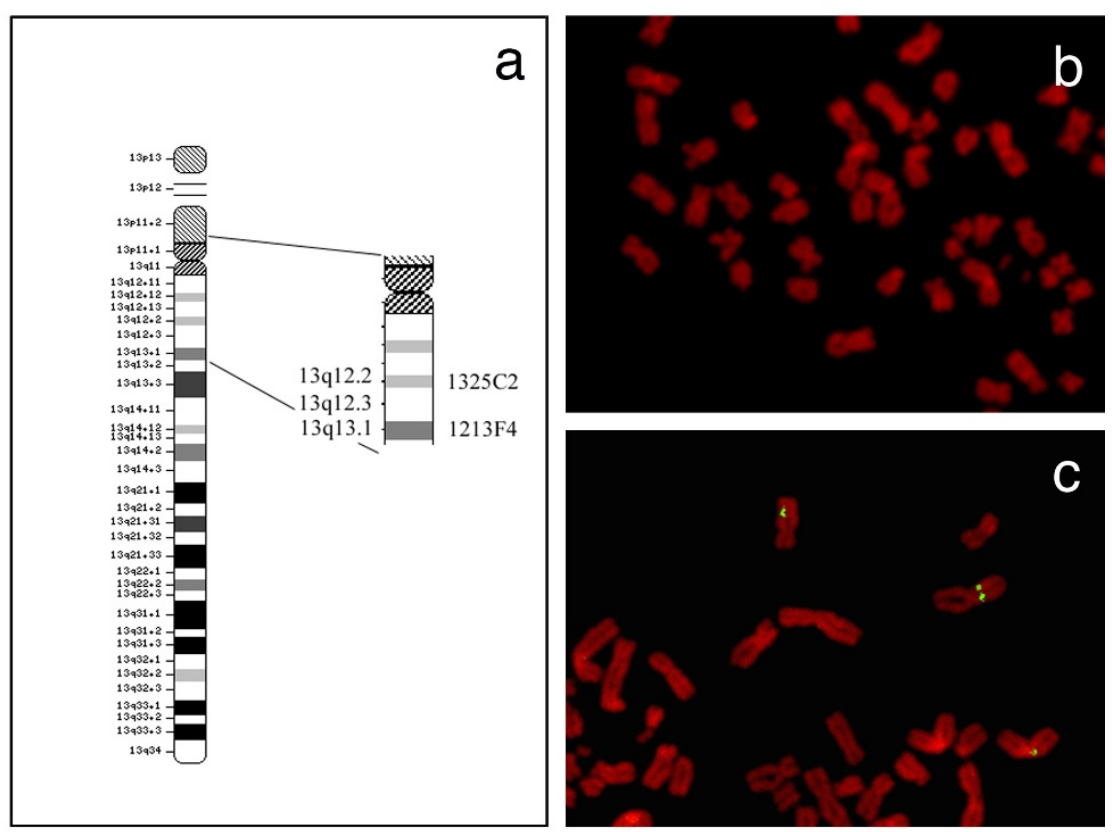

\section{Figure 4}

Fluorescence in-situ hybridization (FISH) for screening of break points for the translocation, $t(9 ; \mid 3)(p|3 ; q| 2)$ in SM-AP5, by using BAC clones. Panel A, mapping of BAC clones of chromosome 9 (a) and FISH for $9 \mathrm{pI} 3.2$ by BAC I537EI2 (b) and for 9p I3.I by BAC I405FI (c). Panel B, mapping of BAC clones of chromosome I3 (a) and FISH for I3qI2.2 by BAC I325C2 (b) and for I3qI3.I by BAC I2I3F4 (c). $\times 800$. Signals of BAC clones, I537EI 2 and I405FI for chromosome 9 pl 3.2 (A-b) and 9p I3.I (A-c), I 325C2 for chromosome I $3 q$ I 2.2 (B-c) were detected as clear single and/or paired fluorescence dots on the translocation $\mathrm{t}(9 ; \mid 3)(\mathrm{pl} ; \mathrm{q} / 2)$ chromosome, while no signal for BAC clone I2I3F4 for chromosome I3qI3.I was seen (B-b). 

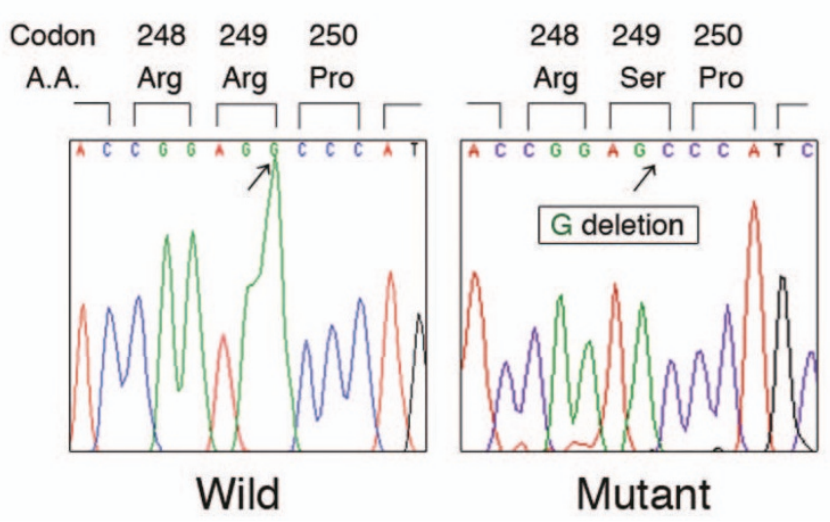

Figure 5

Mutational analysis of the $p 53$ gene in genomic DNA from pleomorphic adenoma cells in the primary culture as well as from the five SM-AP cell systems. PCRamplicons for exons 5, 6 and 7 of the $p 53$ gene were directly sequenced, and the deletion of the last base $G$ of codon 249 (AGG to AG-) in exon 7 was shared by all of the cell systems and the primary culture.

tems showed no P53 protein immunopositivities (not shown).

\section{Discussion}

In the present study, we were successful in establishing the five cell systems, SM-AP1 to SM-AP5, from a benign parotid gland pleomorphic adenoma. We previously suggested a potential of atypical tumor cells scattered in benign pleomorphic adenomas to develop into focal carcinomas and then into tangible forms of carcinoma ex pleomorphic adenoma [3], although it had been questionable whether the presence of these atypical cells within pleomorphic adenoma could be recognized as sources for the secondary onset of malignancy [4-6].

There have been three trials in the literature to establish cell lines/systems from pleomorphic adenomas in which only their malignant or transformed natures of the cells were reported with no definite histological characterization as squamous cell carcinoma [19-21], and two were from carcinoma ex pleomorphic adenomas $[13,22]$, in addition to those from mere primary cultures [7-9,23-27]. In terms of cell shapes in culture, the cell system by Bullerdiek et al. was spindle [22], and CaPA-4 cells by Fujioka et al. [13] were squamous epithelial. In our immunohistochemical study, polygonal-shaped SM-AP1 to SM-AP3 were shown to be duct-epithelial, while spindle-shaped SM-AP4 and SM-AP5 were myoepithelial. In addition, their xenografts presented some ductal (SM-AP1-SM-AP3) or myoepithelial (SM-AP1 and SM-AP2 by plasmacytoid appearances) differentiation.
Interestingly, the two cell lines from carcinoma ex pleomorphic adenoma $[13,22]$ were demonstrated to have characteristics of squamous cell carcinoma when they were transplanted into nude mice, as was also observed in the present study. Although our cell systems lost benign features of pleomorphic and had definite tendencies towards keratinization in xenografts, their histology was not always typical as seen in oral mucosal squamous cell carcinomas ones in terms of their cytoplasm and stroma. SM-AP cells had their characteristic cytoplasm with ground-glass appearances, and their hyaline or myxoid stromata were rich in perlecan and fibronectin and poorly vascularized. These features indicated that they were of pleomorphic adenoma origin. It took longer periods for them to form transplanted tumors, and they had no ulceration or metastasis, indicating that they were not so aggressive.

The five pleomorphic adenoma cell systems cloned in the present study showed aneuploid karyotypes and various kinds of chromosomal abnormalities, of which the translocation, $\operatorname{der}(9) \mathrm{t}(9 ; 13)(\mathrm{p} 13 ; \mathrm{q} 12)$, was stably shared by all of the clones. As a chromosome 9-related alteration, a reciprocal translocation $\mathrm{t}(9: 12)(\mathrm{p} 13-21 ; \mathrm{q} 13-15)$ was found in benign pleomorphic adenomas by Mark et al. [24]. In the present study, we were able to restrict the break points of $\mathrm{t}(9 ; 13)(\mathrm{p} 13 ; \mathrm{q} 12)$ within $9 \mathrm{p} 13.3$ and $13 q 12.3$ in these cell systems. The result indicates that genes located in the distal region of 9p13.3 and the proximal region of 13q12.3 ares missing. The distal region of 9p13.3 is known to contain interferon $\alpha$ cluster (IFNA), a tumor suppressor gene (9p22) [31], methylthioadenosine phosphorylase (MTAP) (9p21) [32], and p16 (9p21) [33], and the break point at 13q12.3 contains IFN-inducible gene, namely the IFI-56K [34]. A role of p16 gene in the secondary onset of malignancy in pleomorphic adenomas has been hypothesized by Suzuki \& Fujioka [33]. Since 9 p13 rearrangements seem to be generated at the stage of pleomorphic adenoma, pleomorphic adenoma could be regarded as substantially malignant in nature even if it has a benign histological feature. The deletions of 9p22 containing IFNA and 9p21 containing MTAP and p16 genes and $9 \mathrm{p}$ allelic losses were also observed in oral squamous cell carcinoma [33,35-37].

None of the five pleomorphic adenoma cell systems in the present study showed any of these translocations involving 8q12, where PLAG1, one of the most extensively investigated genes in pleomorphic adenomas, is located. Astrom et al. [8] claimed that the 8q12 abnormalities are not a requirement for the enhanced expression of PLGA1 in pleomorphic adenoma by using primary cultures of both pleomorphic adenoma and carcinoma ex pleomorphic adenoma with or without $8 \mathrm{q} 12$ abnormalities. Abnormalities such as $\mathrm{t}(6,8)(\mathrm{p} 21-23 ; \mathrm{q} 12)$ [23], 

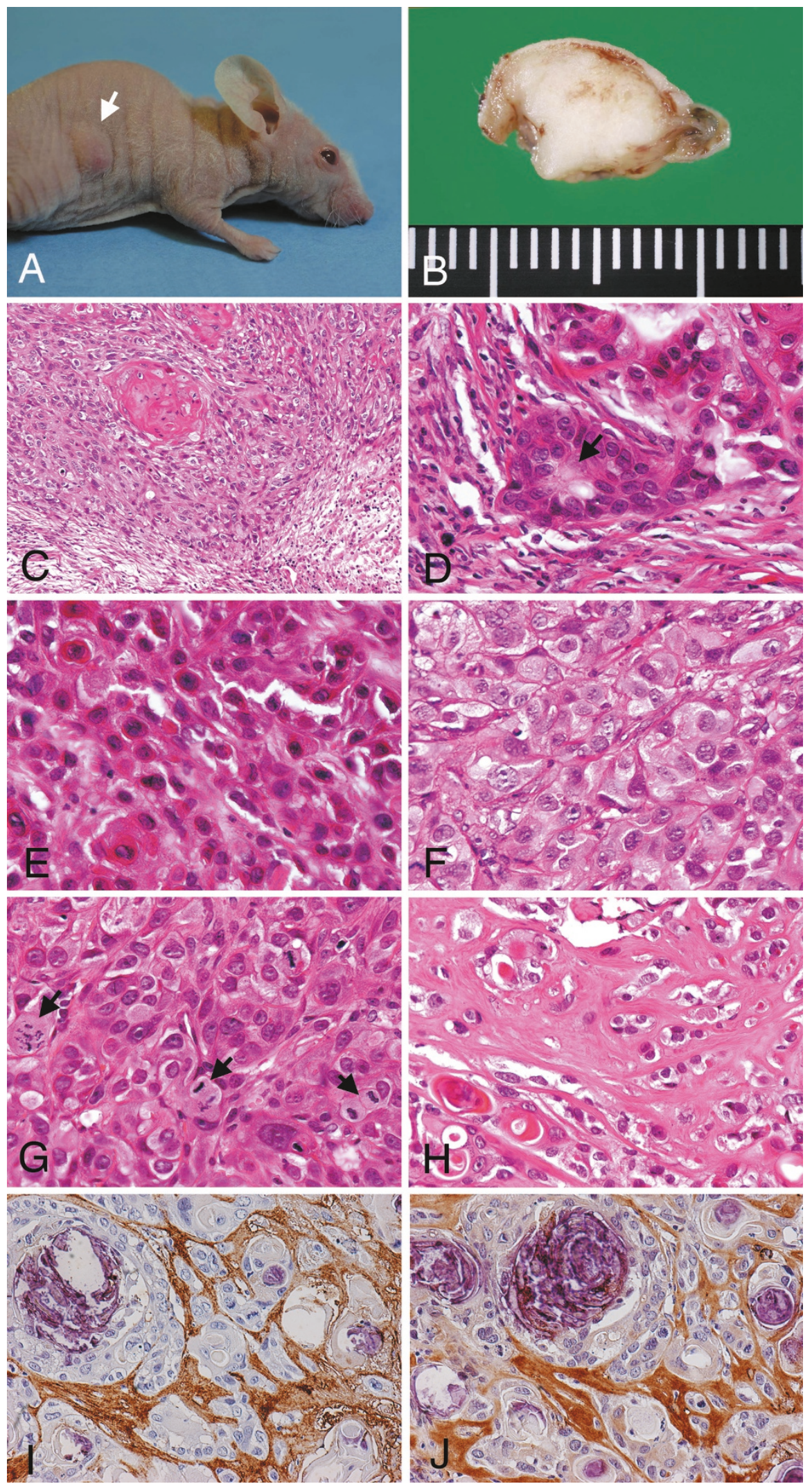

Figure 6 (see legend on next page) 
Figure 6 (see previous page)

Transplanted tumors of SM-AP cell systems in nude mice. Macroscopic view of a tumor mass by SM-AP5 in lateral back in a nude mouse (A); cut surface view of a subcutaneous tumor by SM-API (B); histopathology of transplanted tumors by SM-AP4 (C), SM-API (D, E), SM-AP5 (F, G), and SM-AP3 (H). HE stain, C, × 100; D-G, × 320; H, × 240; immunoperoxidase stains of SM-AP3 transplants for perlecan $(\mathbf{I})$ and fibronectin $(\mathbf{J}), \times 200$, hematoxylin counterstain. SM-AP cells formed subcutaneous tumors measuring about $10 \mathrm{~mm}$ in diameter in nude mice within one to four months $(A)$. The tumors were rather limited to the dermis expanding into the superficial part of the muscle layer but had no capsular structure (B). Histopathologically, the tumors were basically squamous cell carcinomas with definite tendencies towards keratinization with invasive natures, although there was no basal cell alignment along the periphery of the tumor cell nests (C). Around the tumor cell nests, myxoid stroma was induced. SM-API to SM-AP3 cells formed mimics of ductal structures (D), and at the same time, SM-API and SM-AP2 showed plasmacytoid appearances (E). SM-AP4 and SM-AP5 cells formed less differentiated carcinomas composed of tumor cells with ground-glass-like cytoplasm (F). Irrespective of tumors, mitotic figures were frequently observed (G), and the stromata were wide, hyaline, and poor in vascularity and lymphocytic infiltration $(\mathrm{H})$. The hyaline stroma was immunopositive for perlecan (I) and fibronectin (J).

$\mathrm{t}(9 ; 12)(\mathrm{p} 13-21 ; \mathrm{q} 13-15) \quad[24], \quad \operatorname{del}(5)(\mathrm{q} 22-23 ; \mathrm{q} 32-33)$, $\mathrm{t}(10 ; 12)(\mathrm{p} 15 ; \mathrm{q} 14-15)$ [38], and $\mathrm{t}(12 ; ?)(\mathrm{q} 13-15 ; ?)[22]$ found in our cell systems constitute a new finding in pleomorphic adenoma.

Loss of heterozygosity ( $\mathrm{LOH}$ ) has been demonstrated, by using surgical materials, at chromosome arms $8 \mathrm{q}(52 \%)$, $12 q(28 \%)$, and $17 \mathrm{p}(14 \%)$ in benign pleomorphic adenomas and in adenoma components of carcinoma ex pleomorphic adenoma, whereas the ratios of $\mathrm{LOH}$ in $8 \mathrm{q}, 12 \mathrm{q}$ and $17 \mathrm{p}$ loci were enhanced up to $69 \%, 50 \%$, and $69 \%$, respectively, in carcinoma ex pleomorphic adenoma [39]. In our present result, pleomorphic adenoma cell systems tended to decrease numbers of chromosome 17 and abnormalities of add(17)(p11) and add(17)(p13). These chromosomal abnormalities may affect transcription of the $p 53$ gene, which is located in $17 \mathrm{p} 13$.

The present result demonstrating that $p 53$ gene products were not detectable immunohistochemically in the five cell systems both in culture and xenografts are consistent with the data from CaPA-4 cells [13]. In the previous reports, immunohistochemical expressions of P53 protein were not always obtained in tumor cells or in the cases examined (3\% to $41 \%$ for pleomorphic adenoma cases and $41 \%$ to $75 \%$ for carcinoma ex pleomorphic adenoma cases) $[10,11,15,16]$. There may be two interpretations for the non-immunopositivity for $p 53$ gene products in our cell systems: one is that the protein expression lev- els were lower than the sensitivity of the method, and another is that mutated gene products could not be recognized by the antibody, Bp53-11. The latter seems to be more likely in our case because the point mutation in codon \#249 in exon 7, which was shared by all of the cell systems, should have generated a nonsense gene product, which could not be recognized by the antibody whose antigenic site is the transcriptional transactivation domain within the $\mathrm{NH}_{2}$-terminal region [40]. Since we confirmed that this point mutation at codon \#249 even in cells in the primary culture might have existed before cloning transformed SM-AP cells, this suggests that this mutation plays a role in the tumorigenesis of benign pleomorphic adenoma as well as in its malignant transformation. Interestingly, the $\mathrm{G}$ to $\mathrm{A}$ transitional point mutation at the next codon \#248 found in CaPA-4 cells was also found in the surgical tissue samples from the adenoma portion as well as from the carcinoma portion of their original carcinoma ex pleomorphic adenoma [13]. Thus, the mutations of the $p 53$ gene should be considered to be an early event in the malignant transformation.

\section{Conclusion}

The present data suggest that pleomorphic adenoma contains cells with genetic alterations even when its histology is benign and that carcinoma cells may develop from some of the population of benign forms. Whether the atypical cells within benign pleomorphic adenoma [3] can be the direct source for malignant transformation is

Table 3: Tumorgenicity of pleomorphic adenoma cell systems.

\begin{tabular}{ccc}
\hline cell systems & Number of mice with tumors $(\mathrm{n}=2)$ & Mean time of tumor appearance (weeks) \\
\hline SM-API & 2 & 7.5 \\
SM-AP2 & 1 & 9 \\
SM-AP3 & 1 & 19 \\
SM-AP4 & 1 & 5 \\
SM-AP5 & 2 & 9 \\
\hline
\end{tabular}


hard to say. Since all of the xenografted tumors in nude mice were histologically squamous cell carcinomas, the present establishment of pleomorphic adenoma-derived squamous cell carcinoma cells can be regarded as an invitro demonstration of secondary development of malignancy from a benign adenoma. This process may correspond to the clinical form of carcinoma ex pleomorphic adenoma. However, it may be possible at least to speculate that under the circumstances, in which atypical cells are generated, pleomorphic adenoma cells attain some background for the secondary onset of malignancy, which may be generated from the combination of the $p 53$ gene mutation and other chimera genes resulting from the specific translocations involving $\operatorname{der}(9) \mathrm{t}(9 ; 13)(\mathrm{p} 13.3$; q12.3) and other chromosome abnormalities.

\section{Competing interests}

The authors declare that they have no competing interests.

\section{Authors' contributions}

SM carried out cell culture, establishment of cell systems and molecular genetic studies and participated in preparation of the manuscript. JC carried out immunohistochemistry. SS carried out tumor tissue sampling. TT carried out chromosomal analysis. SA participated in sequencing. SM, YS, and NS participated in the design of fluorescence in-situ hybridization (FISH) analysis of human BAC clones. TS conceived the study and participated in its design and coordination and in preparation of manuscript. All authors have read and approved the final manuscript.

\section{Acknowledgements}

This work was supported in part by Grants-in-Aid for Scientific Research and for Young Scientists from the Japan Society for the Promotion of Science and from the Ministry of Education, Culture, Sports, Science and Technology, Japan, and by a grant for the Promotion of Niigata University Research Projects.

\section{References}

I. Gnepp DR, Wening BM: Malignant mixed tumors. In Surgical pathology of the Salivary Glands Edited by: Ellis GL, Auclair PL, Gnepp DR. Philadelphia: W.B. Saunders; 1991:350-368.

2. Ellis GL, Auclair PL: Tumor of the Salivary Glands: Atlas of Tumor Pathology, 3rd Series. Washington, DC: Armed Forces Institute of Pathology; 1996:228-238.

3. Ohtaké S, Cheng J, Ida H, Suzuki M, Ohshiro K, Zhang W, Saku T: Precancerous foci in pleomorphic adenoma of the salivary gland: recognition of focal carcinoma and atypical tumor cells by P53 immunohistochemistry. J Oral Pathol Med 2002, 3I:590-597.

4. Brandwein M, Huvos AG, Dardick I, Thomas MJ, Theise ND: Noninvasive and minimally invasive carcinoma ex mixed tumor: $A$ clinicopathologic and ploidy study of $I 2$ patients with major salivary tumors of low (or no?) malignant potential. Oral Surg Oral Med Oral Pathol Radiol Endod 1996, 81:655-664.

5. Auclair PL, Ellis GL: Atypical features in salivary gland mixed tumors: their relationship to malignant transformation. Mod Pathol 1996, 9:652-657.

6. Takeda Y: An immunohistochemical study of bizarre neoplastic cells in pleomorphic adenoma: its cytological nature and proliferative activity. Pathol Int 1999, 49:993-999.
7. Kas K, Voz ML, Roijer E, Astrom AK, Meyen E, Stenman G, Ven W] Van de: Promoter swapping between the genes for a novel zinc finger protein and beta-catenin in pleomorphic adenomas with t(3;8)(p2I;q I 2) translocations. Nat Genet 1997, I5:170-174.

8. Astrom AK, Voz ML, Kas K, Roijer E, Wedell B, Mandahl N, Ven W, Mark J, Stenman G: Conserved mechanism of PLAGI activation in salivary gland tumors with and without chromosome 8q I 2 abnormalities: identification of SII as a new fusion partner gene. Cancer Res 1999, 59:918-923.

9. Voz ML, Astrom AK, Kas K, Mark J, Stenman G, Ven WJ Van de: The recurrent translocation $\mathrm{t}(5 ; 8)(\mathrm{p} / 3 ; \mathrm{q} / 2)$ in pleomorphic adenomas result in upregulation of PLAGI gene expression under control of the LIFR promoter. Oncogene 1998, 16:1409-1416.

10. Deguchi H, Hamano H, Hayashi Y: c-myc, ras p2I and p53 expression in pleomorphic adenoma and its malignant form of the human salivary glands. Acta Pathol Jpn 1993, 43:4I3-422.

II. Yamamoto Y, Kishimoto Y, Wistuba II, Virmani AK, Vuitch F, Gazder AF, Albores-Saavedra J: DNA analysis at p53 locus in carcinomas arising from pleomorphic adenomas of salivary glands: comparison of molecular study and p53 immunostaining. Pathol Int 1998, 48:265-272.

12. Righi PD, Li YQ, Deutsch M, Mcdonald JS, Wilson KM, Bejarano P, Stambrook PJ, Osterhage D, Nguyen C, Gluckman JL, Pavelic ZP: The role of the $\mathrm{p} 53$ gene in the malignant transformation of pleomorphic adenomas of the parotid gland. Anticancer Res 1994, 14:2253-2258.

13. Fujioka M, Shimada K, Kitazawa S, Maeda S: Molecular characterization of a novel cancer cell line established from human carcinoma in pleomorphic adenoma (caPA-4). Int J Cancer 1996, 67:204-210

14. Weber A, Langhanki L, Schutz A, Gerstner A, Bootz F, Wittekind C, Tannapfel A: Expression profiles of p53, p63, and p73 in benign salivary gland tumors. Virchows Arch 2002, 441:428-436.

15. Lewis JE, Olsen KD, Sebo TJ: Carcinoma ex pleomorphic adenoma: pathologic analysis of $\mathbf{7 3}$ cases. Human Pathol 200I, 32:596-604

16. Karja VJ, Syrjanen KJ, Kurvinen AK, Syrjanen SM: Expression and mutations of p53 in salivary gland tumors. J Oral Pathol Med 1997, 26:217-223.

17. Li X, Tsuji T, Wen S, Mimura Y, Sasaki K, Shinozaki F: Detection of numeric abnormalities of chromosome 17 and $p 53$ deletions by fluorescence in situ hybridization in pleomorphic adenomas and carcinomas in pleomorphic adenoma. Cancer 1997, 79:23|4-2319.

18. Weber A, Langhanki L, Schutz A, Wittekind C, Bootz F, Tannapfel A: Alterations of the INK4a-ARF gene locus in pleomorphic adenoma of the parotid gland. J Pathol 2002, 198:326-334.

19. Kondo T, Muragishi H, Imaizumi M: A cell line from a human salivary gland mixed tumor. Cancer 197I, 27:403-4I0.

20. Jaeger MM, Araujo VC, Kachar B, Jaeger RG: Effect of spatial arrangement of the basement membrane on cultured pleomorphic adenoma cells. Study by immunocytochemistry and electron and conforcal microscopy. Virchows Arch 1997, 430:467-477.

21. Shirasuna K, Sato M, Miyazaki T: A myoepithelial cell line established from a human pleomorphic adenoma arising in minor salivary gland. Cancer 1980, 45:297-305.

22. Bullerdiek J, Hutter KJ, Brandt G, Weinberg M, Belge G, Bartnitzke S: Cytogenetic investigations on a cell line derived from a carcinoma arising in a salivary gland pleomorphic adenoma. Cancer Genet Cytogenet 1990, 44:253-262.

23. Rohen C, Rogalla P, Meyer-Bolte K, Bartnitzke S, Chila R, Bullerdiek $\mathrm{J}$ : Pleomorphic adenomas of the salivary glands: absence of HMGIY rearrangements. Cancer Genet Cytogenet 1999, III:I78-I8I.

24. Mark J, Dahlenfors R, Ekedahl C: Chromosomal Deviations and their specificity in human mixed salivary gland tumors. Anticancer Res 198I, I:49-57.

25. Bullerdiek J, Wobst G, Meyer-Bolte K, Chilla R, Haubrich J, Thoode $B$, Bartnitzke S: Cytogenetic subtyping of $\mathbf{2 2 0}$ salivary gland pleomorphic adenomtas: correlation to occurrence, histological subtype, and in vitro cellular behavior. Cancer Genet Cytogenet 1993, 65:27-31. 
26. Mark J, Dahlenfors R, Wedell B: Impact of the in vitro technique used on the cytogenetic patterns in pleomorphic adenomas. Cancer Genet Cytogenet 1997, 95:9-I5.

27. Johns MM, Westra WH, Califano JA, Eisele D, Koch WM, Sidransky D: Allelotype of salivary gland tumors. Cancer Res 1996, 56: II5I-II54

28. MacDougall M, Thiemann F, Ta H, Hsu P, Chen LS, Snead ML: Temperature sensitive simian virus 40 large $T$ antigen immortalization of murine odontoblast cell cultures: establishment of clonal odontoblast cell line. Connect Tissue Res 1995, 33:97-103.

29. Cheng J, Irié T, Munakata R, Kimura S, Nakamura H, He RG, Liu AR, Saku T: Biosynthesis of basement membrane molecules by salivary adenoid cystic carcinoma cells: an immunofluorescence and confocal microscopic study. Virchows Arch 1995, 426:577-586.

30. Asakawa S, Abe I, Kudoh Y, Kishi N, Wang Y, Kubota R, Kudoh J, Kawasaki K, Minoshima S, Shimizu N: Human BAC library: construction and rapid screening. Gene 1997, I9 I:69-79.

31. Devlin J, Keen AJ, Knowles MA: Homozygous deletion mapping at 9p2 I in bladder carcinoma defines a critical region within 2cM of IFNA. Oncogene 1994, 9:2757-2760.

32. Cannon ALA, Goldgar DE, Meyer LJ, Lewis CM, Anderson DE, Fountain JW, Hegi ME, Wiseman RW, Patty EM, Bala AE, Olopade OI, Diaz MO, Kwiatkowski DJ, Piepkorn M, Zone JJ, Skolnick MH: Assignment of a locus for familial melanoma, MLM, to chromosome 9p I3-p22. Science 1992, 258: I |48-II52.

33. Suzuki H, Fujioka Y: Deletion of pl 6 gene and microsatellite instability in carcinoma arising in pleomorphic adenoma of the parotid gland. Diagnostic Mol Pathol 1998, 7:224-23I.

34. Wathelet MG, Szpirer J, Mols CB, Clauss IM, De Wit L, Islam MQ, Levan G, Horisberger MA, Content J, Szpirer C: Cloning and chromosomal location of human genes inducible by type I interferon. Somat Cell Mol Genet 1988, I4:4I5-426.

35. Nakanishi H, Wang XL, Imai FL, Kato J, Shiiba M, Miya T, Imai Y, Tanzawa $\mathrm{H}$ : Localization of a novel tumor supressor gene loci on chromosome 9p21-22 in oral cancer. Anticancer Res 1999, 19:29-34.

36. van der Riet P, Nawroz H, Hruban RH, Corio R, Tokino k, Koch W, Sidransky D: Frequent loss of chromosome 9p21-22 early in head and neck cancer progression. Cancer Res 1994, 54:II56-I I58.

37. Ishwad CS, Ferrell RE, Rossie KN, Appel BN, Johnson JT, Myers EN, Law JC, Srivastava S, Gollin SM: Loss of heterozygosity of the short arm of chromosomes 3 and 9 in oral cancer. Int J Cancer 1996, 69:1-4.

38. Roijer E, Nordkvist A, Strom AK, Ryd W, Behrendt M, Bullerdiek J, Mark J, Stenman G: Translocation, deletion/amplification, and expression of HMGIC and MDM2 in a carcinoma ex pleomorphic adenoma. Am J Pathol 2002, I60:433-440.

39. El-Naggar AK, Callender D, Coombes MM, Hurr K, Luna MA, Batsakis JG: Molecular genetic alterations in carcinoma ex pleomorphic adenoma: a putative progression model? Genes Chromosomes Cancer 2000, 27:162-168.

40. Stephen CW, Helmine P, Lane DP: Characterisation of epitopes on human p53 using phage-displayed peptide libraries: insights into antibody-peptide interactions. J Mol Biol 1995, 248:58-78

\section{Pre-publication history}

The pre-publication history for this paper can be accessed here:

\section{http://www.biomedcentral.com/1471-2407/9/247/pre} pub
Publish with Biomed Central and every scientist can read your work free of charge

"BioMed Central will be the most significant development for disseminating the results of biomedical research in our lifetime. "

Sir Paul Nurse, Cancer Research UK

Your research papers will be:

- available free of charge to the entire biomedical community

- peer reviewed and published immediately upon acceptance

- cited in PubMed and archived on PubMed Central

- yours - you keep the copyright
BioMedcentral 